\title{
VEDó Attila \\ A Magyar Királyi Csendőrség \\ közbiztonsági tevékenységének megszervezése \\ 1881-1918.
}

Az emberi társadalmakban a nem kívánatos emberi magatartások megelőzésének elsődleges eszköze évezredek óta a rend fenntartására hivatott szervezetek őrködő, pusztán jelenléttel preventív hatást elérő tevékenysége volt. ${ }^{1}$ A magyar rendvédelem történetére — amely már a feudális államalapítást megelözően a törzsi viszonyok között is müködött - is ez volt a jellemző kezdetben a szóbeli szabályozás, majd az írott jogszabályoknak megfelelően. A mindenkori magyar rendvédelem a magyar társadalom fejlettségét tükrözve müködött, összhangban a korabeli európai rendvédelem gyakorlatával, de a magyar sajátosságoknak megfelelően. ${ }^{2}$

A történelem során a jogellenes cselekmények megelózése érdekében megvalósított közbiztonsági szolgálat a rendvédelmi testületek alapfeladatává vált és folyamatosan fejlödött. A francia minta alapján Európa szerte teret hódító csendőrségek, mint katonailag szervezett közbiztonsági őrtestületek ${ }^{3}$ szervezetük és módszereik folytán képesek voltak a rendőrségeknél eredményesebben a ritkán lakott vidéki területeken is hatékony preventív müködésre. ${ }^{4}$

A XIX. század végére Magyarországon is egyértelművé vált, hogy a „betyárvilág” felszámolása és a városoktól távol eső területek rendjének fenntartása országosan szervezett, központosított és korszerü megelőző közbiztonsági szolgálatot megvalósítani képes szervezetet követel. ${ }^{5}$ Ez a felismerés vezetett a Magyar Királyi Csendőrség országos megszervezéséhez 1881-től. A testület évtizedeken át kimagasló eredményességgel látta el feladatait és az ország legfélreesőbb területein is képes volt garantálni a polgárok élet- és vagyonbiztonságát. ${ }^{6}$

Kutatásommal arra keresem a választ, hogy a mai rendőri állomány harmadánál is kevesebb erővel, a mai államterület háromszorosának megfelelő müködési területen csaknem 20000000 főnyi lakosság körében - ekkor még a magyarországi népesség döntő többsége vidéken élt — a Magyar Királyi Csendőrség hogyan volt képes azon kimagasló eredményei elérésére, melyet azóta sem volt képes egyetlen magyar rendvédelmi testület sem elérni. Milyen módszerek és szervezési elvek segítségével valósította meg a rendfenntartást, és milyen ma is felhasználható tapasztalatokat szerzett a müködése során? A testület fejlődésével bővültek szolgálati feladatai és speciális feladatkörü szervezeti elemek jöttek létre, melyek a mai értelemben vett szolgálati ágaknak feleltek meg (pl. közlekedési-, vasúti csendőrség, bünügyi szolgálat, stb.). Jelen írásomban azonban csak a közbiztonsági szolgálatot, mint a szervezet legalapvetőbb tevekénységét kívánom elemezni a szervezet megalakulásától 1918-ig. Hogyan volt képes tehát a Magyar Királyi Csendőrség az egységnyi területre ma rendelkezésre álló fegyveres rendvédelmi erők 1/9-ed részével hatékonyan ellátni feladatait a modern közlekedési és telekommunikációs eszközök kora előtt?

Véleményem szerint a megoldás a váratlanságban, a kiképzésben, és a profiltisztaságban, a szolgálat megelözö jellegében a hatósági területén az állandó jelenlétében, a személyi állomány folyamatos és célirányos felkészülésében valamint a magas szintü hivatásszeretetben és erkölcsösségben keresendő. Az okok tehát összetettek, azonban jelen írás keretében nyilvánvalóan a közrendvédelmi szolgálat ellátásával kapcsolatos körülmények bemutatására nyílik csupán lehetőség.

A vidék útjait vagy ösvényeit járó vándor soha nem tudhatta, hol és mikor bukkan fel a csendőr járôr. Ez biztonságot adott a jogkövető polgároknak és nehezítette a jogellenes cselekményeket elkövetők dolgát, csökkentette a bünalkalmakat. A csendörök szigorú napirend szerint éltek, és szolgálaton kívüli idejük nagy részét szervezett képzéssel vagy önképzéssel töltötték, melyet az őrsök önerőből valósítottak meg. Ez biztosította, hogy bár a járőr legtöbbször nem tudott segítséget kérni intézkedéseihez, azokat mégis eredményesen képes volt befejezni. A korabeli rendvédelmi testületek nem rendelkeztek hazai és nemzetközi összehasonlításban sem különleges jogkörökkel, illetve csúcstechnikákkal. Eredményeik kulcsa a személyi állomány jellegében és a vezetés színvonalában rejlett. Gyakorlatilag ismeretlen fogalom volt — más korabeli magyar rendvédelmi testületekhez hasonlóan - a csendőrök körében a korrupció, amely egyrészt a testületi tagok erkölcsi színvonalának, másrészt pedig annak a következménye volt, hogy a megbecsült társadalmi helyzetüket a rendvédelmi testületek tagjai nem kívánták kockáztatni. Az állami alkalmazottak ellátásának alapelve ugyanis az volt, hogy az állam köteles alkalmazottai számára a társadalmi állásukhoz méltó életvitelhez szükséges feltételeket biztosítani. E feltételek pedig nem csupán a fizetésben merültek ki. Az állam az érintettek számára a családjuk nagyságától és a családfö által betöltött beosztás szintjétől függő méretű és komfortfokozatú lakást biztosított az állami alkalmazottak számára a lakbér 
összegének teljes megtérítésével, 40 éves szolgálati viszony után pedig az e körbe tartozók fizetésük 100 \%-ával mehettek nyugdíjba. ${ }^{7}$ Profiltisztaság alatt azt értem, hogy a járőrnek legtöbbször csak felfednie, megszakítania kellett a jogsértő cselekményt, az ennek alapján indult eljárást azonban általában más állami szerv folytatta le. A vizsgált időszakban ugyanis élesen elkülönült a rendőrhatóság és a rendőrközeg fogalma. A Magyar Királyi Csendőrség ugyanis — ellentétben a rendőrségekkel, amely testületek egyszerre voltak rendőrhatóságok és rendőrközegek — csupán rendőri közeg volt, hatósági jogkörrel a testület nem rendelkezett. A rendörségek esetében pedig a rendőrhatósági jogkör érvényesítésére a belügyminiszter hatalmazott fel rendőrtiszteket a jogi végzettségü tisztek közül. ${ }^{8}$

Mivel az adminisztratív kötelezettségek nem vonták el a müködési területröl, visszatérhetett alapvető szolgálati feladatához. A fenti kérdések napjainkban is foglalkoztatják a rendvédelmi szakembereket, így a téma deduktív, feltáró módszerrel történő kutatása olyan törvényszerüségek és összefüggések felismeréséhez vezethet, melyek ma is segítik a rendőrök munkáját.

A tanulmány elkészítésekor, a téma kidolgozásakor a Magyar Királyi Csendőrség történetét feltáró könyveket ${ }^{9}$ és tanulmányokat ${ }^{10}$ hasznosítottam, továbbá a korabeli szakfolyóirat a „Csendörség Lapok" "11 cikkeit, illetve a testületre vonatkozóan alapvetően a témakörtekintetében keletkezett törvényeket és rendeleteket ${ }^{12}$, valamint a vonatkozó testületi szabályzatokat. ${ }^{13}$

\section{A csendőrség szervezete}

Először is szükséges szót ejteni a csendőrség magyarországi megjelenéséről, fejlődéséről. A csendőri szervezet a Magyar Királyi Csendőrség felállítását megelőzően sem volt ismeretlen hazánkban. Először 1849. augusztusában Pesten indult meg egy császári csendőrezred szervezése, majd egy 1850. I. 18-án kelt legfelsőbb uralkodói elhatározással elrendelték a birodalmi csendőrség, a „zsandárság” felállítását az egész HABSBURG-birodalom területére. Irányítását a Bécsben székelő csendőrségi felügyelö látta el. ${ }^{14}$

A birodalmi csendörség a mintaadó francia-lombardiai hagyományt követte. 1851-ben külön rendvédelmi birodalmi főparancsnokságként Legfelsőbb Országos Rendőrhatóságot hoztak létre a birodalmi rendőrség és csendőrség közös föparancsnokságaként az uralkodó közvetlen alárendeltségében. E szervezet élére pedig Julius Jacob von HAYNAU táborszernagy korábbi jobbkezét, majd a birodalmi csendőrség föparancsnokát Franz Johann KEMPEN von Fichtenstam táborszernagyot helyezték a csendőr-főparancsnoki beosztása meghagyásával. ${ }^{15}$ 1867-ben a bécsi udvar a kiegyezési tárgyalásoknak megfelelően a Magyarországon állomásozó csendőrséget feloszlatta, Horvát-Szlavonország és Erdély ezredeit azonban megtartotta. Ezt követően a magyar városok közbiztonságának fenntartása általánosságban a városi rendőrségekre, a vidéki területeké a pandúrokra hárult. A belső rend egyre tarthatatlanabb állapotának orvoslására életre hívott új magyar csendőrség az erdélyi csendőr ezred bázisán alakult meg hosszú évek előkészítő munkája nyomán. ${ }^{16}$

Az országos csendörségi szervezet a lombardiai mintát követve öt szinten szerveződött. Alapeleme csendőr örs volt, amely a közbiztonsági szolgálat ellátásáért általánosan felelt müködési területén. A következő szervezeti szinten a szakasz, több szakaszt összefogó struktúrában pedig a szárnyparancsnokság müködött. A következö szint a csendör kerület volt, ami a lombardiai ezred- és a francia légion-szintnek felel meg. Az ötödik szint a csendőrség felügyelöje volt. 1886-ban a Magyar Királyi Csendőrség szervezetének az egész országra való kiterjesztését követően a Magyar Királyságban 6 csendőr kerület, 25 szárny, 62 szakasz és 966 őrs müködött. Egy kerület 6-8 szárnyból, egy szárny 2-3 szakaszból, egy szakasz 3-6 őrsből állt. Az alapfeladatot ellátó őrsök gyalogos, lovas vagy vegyes szervezésủek lehettek, létszámuk pedig általában 4-6 fö, illetve 8-12 fő között mozgott az őrs működési területének a jellegétől függően. ${ }^{17}$

Ahol azt a speciális közbiztonsági körülmények szükségessé tették a testület úgynevezett különítményeket, ideiglenes szervezeti elemeket is felállított. Létszámuk 20 fö körül alakult és jellemzően szezonális nyaralóhelyeken, tömeges idénymunkák környékén települtek. ${ }^{18}$

A szervezet sikerei hatására a belügyi és a honvédelmi tárca már 1893-ban együttesen fontolgatta a szervezet mennyiségi fejlesztését. A közbiztonság gyors és határozott helyreállítása elismerést hozott a testületnek, de felszínre hozta a szervezeti struktúra korai hibáit is. A parancsnokságok és az alárendelt szervezeti elemek között túlságosan nagyok voltak a távolságok. Az 1890-es években létezett olyan örs, amely felettes szakasz-parancsnokságától $142 \mathrm{~km}$, míg szárny-parancsnokságától $246,5 \mathrm{~km}$ távolságban müködött. ${ }^{19}$

Túlzottan nagynak bizonyultak a müködési területek is, ezért a testület szervezeteinek számát több lépcsőben növelték. A szervezet-gyarapítás első üteme a kilencvenes években zajlott le, mely során 
elsősorban Erdélyben növelték az örsök számát. A szervezet-fejlesztési munkálatok második jelentős fázisa 1903-ban vette kezdetét 242 új örs létrehozásával. Az új szervezeti egységek nem jelentették azonban a személyi állomány arányos növekedését, sokkal inkább újra elosztását. Szintén 1903-ban három új kerület felállításáról is törvényt hozott az országgyülés, melyek közül azonban csak kettőt szerveztek meg: a brassóit (VII. sz.) és a debrecenit (VIII.sz.). ${ }^{20}$

1913-ra a Magyar Királyi Csendőrség 8 kerület-parancsnokságból, 57 szárny-parancsnokságból, 136 szakasz-parancsnokságból, 683 járásőrmesterségből és 2028 örsből álló szervezetté fejlődött. ${ }^{21}$

A csendőrség müködési területe alapvetően a vidéki területekre terjedt ki, a városokra nem. Lehetőség volt azonban arra, hogy díjazás ellenében a csendőrség tartsa fenn egyes városok rendjét is. ${ }^{22}$ Bár ezzel számos város élt, azonban kizárólag a külterületeik tekintetében, így a Magyar Királyi Csendőrség alapvetően a vidéki területek rendfenntartó szervezete maradt.

\section{A járőrszolgálat megszervezése és végrehajtása}

Az I. világháborúig tartó folyamatos szervezetfejlesztések egyértelmü törekvése volt az alapfeladatot ellátó szervezeti elemek, vagyis az őrsök számának növelése. Ez általában a személyi állomány gyarapodásával is együtt járt, azonban sokszor csak újraelosztást, újrarendezést jelentett. A csendőr őrs szolgálati tevékenységei három csoportba voltak besorolhatók, melyek a rendes szolgálat, a felhívás vagy megkeresés alapján más állami szervnek teljesített szolgálat, valamint a parancsnokok által megvalósított ellenőrző szolgálat voltak. ${ }^{23}$

A közbiztonsági megelőző szolgálat a rendes szolgálat körébe tartozott. A korabeli szakirodalom a járőrözéssel megvalósított, őrködő jellegü jelenléti tevékenységet következetesen preventív vagy megelőző szolgáltnak nevezte. A szakkönyvek és szabályzatok e körben említik a rendőri felügyelet alá helyezés és rendőri kitiltás intézményét is, valamint a rovott múltúak nyilvántartásának vezetését, ez azonban kívül esik jelen írás tárgykörén.

Bár a Magyar királyi Csendőrség szervezetében léteztek lovas őrsök és kerületenként lovas alosztályok is, a testület elsődlegesen gyalogosan látta el feladatait. Egy fönek havi 180 órát kellett járőrszolgálatban eltöltenie, melynek 1/3 része pihenő vagy lesállás volt. A folyamatban levö ügyek nyomozása vagy ezekkel kapcsolatos egyéb ügyintézés további 60 órát és számtalan gyalogosan megtett kilométert jelentett havonta. ${ }^{24}$ Egy korabeli számítás szerint a csendőr egy évben $2860 \mathrm{~km}$-t gyalogolt, azaz mire örmester lehetett legalább $11400 \mathrm{~km}$-t, teljes szolgálati ideje alatt pedig 114400 km-t tett meg gyalogosan időjárástól, évszaktól, napszaktól függetlenül. ${ }^{25}$ A járőrszolgálat ideje akár a 24-48 órát is elérhette, bár általában a 12-16 órás szolgálati idő volt a leggyakoribb, ezért a járőrök rövid és hosszú pihenőket tarthattak. A hosszú pihenőket erre a célra szolgáló pihenőszobákban töltötték. ${ }^{26}$

Az őrsök múködési területét őrjáratokra osztották fel, melyekbe valamennyi lakott és lakatlan hely ellenőrzése beletartozott. Az „Örjárati beosztást” az őrs-parancsnok állította össze és a kerületparancsnokság hagyta jóvá. ${ }^{27} \mathrm{~A}$ járörök nem a forgalmas utakon, hanem föként az ösvényeken, mellékutakon portyáztak. Haladási ütemük 7,5 km útra 2 óra volt, ami lassúnak számít. A vendéglőkbe vagy csárdákba csak ellenőrzés céljából léphettek be. ${ }^{28} \mathrm{~A}$ járőrszolgálatok tervezésénél annyira komolyan vették a teljes müködési terület „leportyázását”, hogy az őrjáratok útvonalainak utolsó pontja és a szomszédos őrs őrjáratainak utolsó tereptárgya közötti terület ellenőrzését is rendszeresen megszervezték. Az ilyen „sarkalatos tereptárgyakat” járőrtalálkozásokkal ellenőrizték, vagyis a két szomszédos őrs járőre végigjárva saját őrjáratát előre meghatározott órában találkozott az illetékességi terület határán. ${ }^{29}$

A kétfős járőr menetvonala, a pihenők és lesállások, figyelések helye előre meghatározott volt. A járőrt az eligazító őrs-parancsnok „Szolgálati lappal” látta el, melyre a szolgálati feladatot a parancsnok, annak megvalósulását, a szolgálatban érintett helyeket, időpontokat, ellenörzött személyeket a végrehajtó járőrvezető jegyezte fel. ${ }^{30}$ A járőr a meghatározott menetvonalról csak rendkívüli esetben térhetett le, melyet az őrs-parancsnoknak lehetőleg a következő távíró vagy távbeszélö állomás igénybevételével, ha ez nem volt lehetséges bevonulását követően szolgálati jeggyel jelentett. ${ }^{31}$

A szolgálati utasítás szigorú szabályokat állapított meg a járőrszolgálat ellátására, melybe az is beletartozott, hogy a járőrök szükségtelenül lehetőleg még egymással se beszélgessenek. A járőrszolgálat váratlanságát azzal biztosították, hogy a portyázás során a kijelölt tereptárgyak között az oda- és visszautat más útvonalon kellett megtenni, így a csendőr nagyobb területen tudott megjelenni. A járőr különböző helyeken és időpontokban történő váratlan felbukkanása visszatartotta az alkalmi bünelkövetőket és óvatosságra intette az ,ismert büntetteseket” is. A gyalogos csendőrök igyekeztek 
minél csendesebben közlekedni és időről időre rejtett figyelést, úgynevezett lesállást foglaltak. Egy óránál hosszabb lesállást az őrsparancsnok írt elö, ennél rövidebbet azonban a járőrvezető saját elhatározásból bármikor teljesíthetett. Lest ismert bünelkövetők házánál, községek bejáratainál, útkereszteződésekben, postahivataloknál és csárdáknál kellett tartani. Mivel a csendőr lakott területeken is a mellékutakat használta lehetősége volt észlelni a melléképületekből kiszürődő zajokat, az állatok nyugtalanságát az istállókban és lesállásban megállapítani, hogy jogsértés van-e folyamatban. ${ }^{32}$

A járőr jól ismerte az őrskörletet és a lakosokat, az átutazókat ellenőrizte, a területre költözőkkel pedig mielőbb megismerkedett, felmérte közbiztonsági kockázatukat. Szükség esetén a területre költöző gyanús egyén adatait a csendőr feljegyezte és jelentést tett őrs-parancsnokának. A parancsnok az eligazítások alkalmával ismertette azokat a többi járőrrel és megkereste a beköltöző előző lakhelye szerint illetékes őrsöt a személyre vonatkozóan. ${ }^{33}$

Összességében tehát elmondható, hogy a szervezet hatékony és hosszú időn keresztül sikeres közbiztonsági járőrszolgálatot volt képes megvalósítani, ami nagyban hozzájárult a jogellenes cselekmények megelőzéséhez. A bárhol bármikor felbukkanó csendőrök hatására a tilosban járók kétszer is meggondolták szándékaikat, hiszen nem tudhatták, hogy nem lép-e ki az első fa mögül a lesállást végrehajtó csendőr. A szolgálatellátás rendje és az alkalmazott módszerek a kor szakmai színvonalához igazodtak és európai szintű elismerést vívtak ki a testületnek. A hatékonyság egyik alappillére, a váratlanság tehát nagyban hozzájárult a szervezet sikereihez.

\section{A személyi állomány képzése és az önképzés}

A katonai rend és fegyelem nemcsak a szolgálat ellátása során, hanem a szolgálaton kívül is rányomta bélyegét a csendőrök mindennapjaira. A Magyar Királyi Csendőrség katonailag szervezett fegyveres örtestület volt, ami alaptevékenységét tekintve nem katonai, hanem közbiztonsági feladatokat látott el, a személyi állomány elhelyezése és élete azonban katonai elvek alapján szerveződött ${ }^{34}$, bár a testület — mint rendvédelmi szervezet - a Magyar Királyi Belügyminisztérium irányítása alá tartozott. ${ }^{35} \mathrm{~A}$ járőrök kiindulási és beérkezési helye, valamint lakhelye az őrsépület volt. A csendőr őrs általában a falu főutcáján állt, melynek egy kisebb átalakításokon átesett parasztház adott otthont kerttel, saját kúttal és állattartási lehetőségekkel. Az örs így önellátó módon gazdálkodhatott. ${ }^{36} \mathrm{Az}$ örsépület általában 2-3 szobából, az őrsirodából, egyben az őrsparancsnok hálóhelyéből, a konyhából, a kamrából és esetleg további kiszolgáló helyiségekből állt. A berendezési tárgyakat, sőt azok helyét is szabályzat határozta meg. ${ }^{37}$

Az őrs bár a falu központjában állt, mai szemmel nézve mégis a külvilágtól elzártan müködött. Közeli távíró-kapcsolattal csak az 1920-as évek elejére, telefonnal pedig csak a '30-as évek közepére rendelkeztek az őrsök. ${ }^{38}$

A csendőrök élete nyáron 6, télen 7 órakor kezdődött, egy órával ezután az örs-parancsnok ellenőrizte a laktanya rendjét és eligazította állományát. A járőrszolgálatba vezényeltek kiindulását követően az őrsön maradóknak fél órás gyakorlati, majd 3 órás elméleti képzés kezdődött. A gyakorlati foglalkozás célba lövés vagy kardvívás lehetett, míg az elméleti oktatás keretében a fiatal csendőröket idősebb társaik oktatták. Ebéd után további két óra képzési idő állt rendelkezésre. Itt volt lehetőség az egyéni munkafüzetekben kapott feladatok megoldására, melyeket az őrs-parancsnok határozott meg a korábbi képzéseken (pl. készítsen „tényvázlatot” egy elfogásról, vagy írja le milyen intézkedést tenne bizonyos jogsértések esetén, stb.). ${ }^{39}$

A szervezeten belüli előmenetelhez kapcsolódó központi szervezésü tanfolyamok mellett az ôrsök képzési tevékenysége volt a legmeghatározóbb a személyi állomány felkészültsége szempontjából. Az elméleti foglalkozásokon kerültek feldolgozásra a napi munkát befolyásoló jogszabályok is, és lehetőség volt azok alkalmazását konkrét, mindenki számára ismert helyekhez és személyekhez kötni, ami megkönnyítette azok értelmezését (például az aratásra vonatkozó tüzrendészeti szabályok feldolgozásakor a foglalkozásvezető felidézhetett egy előző évi tủzesetet vagy név szerint felhívhatta a figyelmet a szabályokat gyakran megszegő gazdákra). A képzés így speciálisabb, az adott őrskörlet adottságaihoz igazodó lehetett és témáját legtöbbször a napi élet aktualitásai adták. Fontos volt, hogy a csendör a saját feladatával kapcsolatos ismereteket sajátítsa el, ezért gyakran külön írásos feladatot is adott az őrsparancsnok, ami jelentések, értesítések írásából, helyszínvázlat rajzolásából állt.

A helyi képzési rendszer tehát képes volt az adott kor átlagos iskolázottsági szintjének megfelelő vidéki emberekből válogatott csendőrök sikeres szakmai felkészitésére, és az állomány meglévő hely- és személyismeretét felhasználva előre számolni bizonyos veszélyeztető hatásokkal. 


\section{A felfedett jogsértések dokumentálása, adminisztratív feladatok}

Az adminisztratív feladatok alóli részbeni mentesülés a harmadik lényeges körülmény, amely véleményem szerint nagyban hozzájárult a szervezet sikereihez. A képzési rendszer alapvető célja és egyben következménye az volt, hogy a csendőrök készség szinten képesek legyenek végrehajtani saját feladataikat, de azokat viszonylag szüken jelölték meg. A szervezetnek nem volt célja, hogy a közigazgatás és igazságszolgáltatás teljes vertikumát felölelő ismereteket adjon állományának, nem akart belőlük jogászt vagy főszolgabírót képezni. A csendőrt katonának tekintette, akinek elsődleges feladata a büncselekmények megelőzése, az elkövetők elfogása és az illetékes hatóságoknak történő átadása. Ehhez mérten a csendőrök adminisztrációs tevékenysége - bár nem nélkülözte az alaposságot és a szakmai megfelelőséget - egyszerünek volt mondható. A csendőr a felhívásra teljesített szolgálatok során történtekről szükség esetén értesítést vagy jelentést írt, a saját kezdeményezésủ intézkedésekről tényvázlatot készített. ${ }^{40} \mathrm{~A}$ jogsértés elkövetőit feljelentés készítése mellett az illetékes hatóságnak adta át, a tudomására jutott eseményeket pedig szolgálati jegyen jelentette örsparancsnokának. A járőrök jelentéseit az örsön vezetett szolgálati könyvbe vezették be. ${ }^{41}$

Összességében elmondható, hogy a járőrszolgálatban tett intézkedések dokumentálása kevésbé, míg azok helyes végrehajtása nagyobb súllyal számított a mindennapi munkában, így a papírmunka nem mehetett az őrskörletben valóban eltöltött szolgálati idő rovására. Egyszerűen fogalmazva a csendőr annyit tudott a különböző hatósági eljárásokról, amennyi a feladataihoz szükséges volt, azt azonban képes volt magabiztosan végrehajtani és megfelelő szakmai színvonalon dokumentálni.

\section{Összefoglalás}

Megállapítható tehát, hogy a Magyar Királyi Csendőrség szervezeti sikerei az értékelt több évtizedes időszakban visszavezethetők - a közbiztonsági szolgálat teljesítése tekintetében — a kutatás kiindulási pontjaként megjelölt váratlanságra, képzésre és profiltisztaságra. A testületre jellemzö szolgálati rend és munkamódszerek kiállták az idő próbáját és a két világháború közötti időszakban sem változtak meg lényegüket tekintve. Bár a képzési rendszer folyamatosan fejlödött és intézményesedett, alapját mindvégig az örsök felkészítő tevékenysége, a próbacsendőrök kiképzése és nevelése jelentette. A megszerezett ismeretek a hatékony szolgálatellátást segítették és a gyakorlatban alkalmazott eljárásrendekre készítették fel a személyi állományt. A járőrszolgálatban előforduló eseményekre történő reagálás mellett azok helyes adminisztrációjára is hangsúlyt fektettek annak szem elött tartásával, hogy a papír mögött ne vesszen el a tartalom.

A járőrszolgálat ekkor kialakított szervezési elvei napjainkig éreztetik hatásukat a közbiztonsági szolgálatban. Az általános rendőrségi feladatokat ellátó szervezet közrendvédelmi szolgálati ága ma is arra törekszik, hogy a demonstratív jelenlét és rejtett ellenőrzés, a folyamatos közterületi megjelenés és váratlanság kombinációjával megelőzze a jogsértő cselekmények elkövetését, garantálja a polgárok élet- és vagyonbiztonságát. A testület öröksége mintát adhat a korszerü rendvédelmi szervezetek működéséhez és sikerei fejlődésre ösztönözhetik azokat.

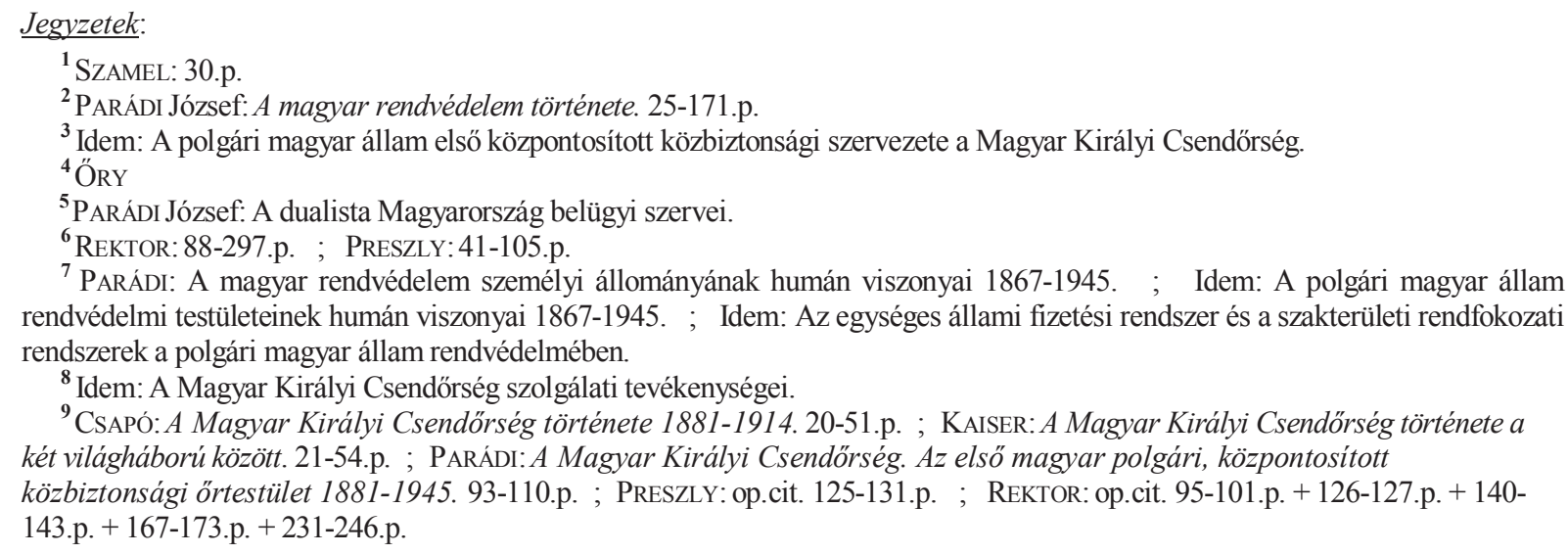


${ }^{10}$ A Magyar Királyi Csendőrségröl szóló tanulmányok döntő többsége a Rendvédelem-történeti Füzetek (Acta Historae Praesidii Ordinis), HU-ISSN 1216-6774 periodikában jelentek.

ARTNER: Egy közbiztonsági őrtestület útja Párizstól — Itálián és Ausztrián keresztül — Budapestig. ; Eadem: A Magyar Királyi Csendörség és a városok. ; ARTNER — PARÁDI — ZEIDLER ; ARTNER: Az osztrák csendörség 1848-1938. ; Eadem: A bajor csendőrség a XX. század húszas éveiben. ; BACSA ; BODA ; CSAPÓ: A Magyar Királyi Csendőrség fegyverhasználati jogáról 1881-1914. ; Idem: A csendőrség és a városok 1881-1914. ; Idem: Erdély csendőrsége az átmenet éveiben 1867-1881. CsÓKA ; DAVOlA: A Magyar Királyi Csendőrség határőrizeti feladatai 1912-ben. ; Idem: A tábori csendőrség, mint a katonai rendőrség elődje. ; Idem: Fényképezés a Magyar Királyi Csendőrségnél. ; ERNYES ; FAZEKAS ; ForRÓ: A csendőrség története. A csendőr őrs. ; Idem: A csendőr kerület rendvédelmi tevékenységének értékelése. ; Idem: A székesfehérvári csendőrkerület teendői a vagyon elleni bűncselekmények megelőzésében és felderítésében. ; Idem: A székesfehérvári csendőrkerület kapcsolata a közigazgatással. ; Idem: Csendőrségtörténeti kutatásaim tapasztalatai. ; Idem: A polgári magyar állam központosított közbiztonsági örtestületének közrendvédelmi szolgálata. ; Idem: A Magyar Királyi Csendőrség és a Fejér vármegyei zsidó deportálás. ; Idem: A székesfehérvári csendőr kerület küzdelme Fejér vármegye közbiztonságáért 1884-1945. ; Idem: A magyar csendőrség Kelet-Dunántúl román megszállásakor. ; GEBHARDT : Die Österreichische Gendarmerie in XX. Jáhrhundert. [Az osztrák csendőrség a XX. században.] ; Idem: Die miliärische Organisation der Österreichischen Gendarmerie von 1849 bis 1918. [A katonailag szervezett osztrák csendőrség 1849-től 1918-ig.] ； HEGEDüs: A Magyar Királyi Csendőrség harc- és gépjármüvei. ; HEGEDÜS - FRÖCHLICH: Forgópisztolyok a honvéd lovasságnál és a Magyar Királyi Csendőrség lovas szervezeti elemeinél. ; HeszTERA: Die Kommandostrukturen der Gendarmerie von 1850 bis 1993. [A csendőrség parancsnoksági rendszere 1850-1993 között.] ； ILLÉSFALVI: A németek által megszállt Bánság helyzete 1941-ben, a Magyar Királyi Csendőrség Központi Nyomozó Parancsnokságának jelentései alapján. ; KAISER: Az őrs mindennapi élete. op.cit. ; Idem: A csendőr őrs gazdaságvédelemmel kapcsolatos feladatai a két világháború között. ; KÁLMÁN: A Magyar Királyi Csendőrség tevékenysége Somogy vármegyében a megalakulástól 1903-ig. ; Idem: Somogy vármegye bünüldözési tapasztalatai a kiegyezéstől a I. vh-ig. ; KESERŰ: Rendőrség és csendőrség Magyarország hadbalépésétől a hadműveletek befejezéséig. ; Idem: A Magyar Királyi Csendőrség a második világháború hadmüveleteiben. ; KIss Gábor: Csendőrök az emigrációban. ; Kiss István Géza: A Magyar Királyi csendőrség hagyományai, muzeális emlékanyagainak örzési helyei hazánkban és külföldön. ； KOMÁROMI ; MARKÓ ; OLASZ ; ÖRY: op.cit. ; PARÁDI Ákos: Ludovikai indítvány a magyar csendőrség létrehozására. ; Idem: Hivatástörténet-gondozás a Magyar Királyi Csendőrségnél. ; PARÁDI József: A dualizmus közrendvédelmi szerveinek jellemzői és tevékenységük tapasztalatai. ; Idem: A Magyar Királyi Csendőrség megalakulása és müködése 1881-1918. ; Idem: A határszéli csendőrség állambiztonsági feladatai. ; Idem: A csendőr tisztképzés és a fizetési oszályba sorolt állami alkalmazottak szakvizsga rendszere. ; Idem: A csendörség magyarországi története. ; Idem: Tények és érzelmek egy hajdani magyar rendvédelmi testület története kapcsán. ; Idem: A Magyar Királyi Csendőrség határőrizeti szolgálata. ; Idem: A Magyar Királyi Csendőrség szervezete. ; Idem: A Magyar Királyi Csendőrség szolgálati tevékenységei. op.cit. ; Idem: A csendőrség teendői az Osztrák-Magyar Monarchia Magyar Királysága külső határainak örzésében. ; Idem: A XIX-XX. századi magyar rendszerváltozások és a csendőrség. ; Idem: Az Osztrák-Magyar Monarchia Magyar Királyságának határszéli csendőrsége. ; Idem: A Császári Királyi Csendőrség Magyarországon. ; PERJÉSI ; RAVASZ ; SALlAI: A határszéli csendőrség fegyverhasználata. ; Idem: Francia, osztrák, magyar csendőrség fegyverhasználata a XIX. században. ; SÁGVÁRI ; SIMON : A Magyar Királyi Csendőrség szolgálati teendői a vagyonbiztonság ellen irányuló büncselekmények megelőzésében és felderítésében. ; Idem: Egy kiérdemelt emlékbélyeg és egy nem érdemelt megbélyegzés története. ; SuBA: A Magyar Királyi Csendőrség szerepe az északi demarkációs vonalon 1919-1923. ; Idem: Határcsendőr zászlóaljak 1919-1921. Áttérés a katonai határőrizetre. ; Idem: A Magyar Királyi Csendőrség létszámának tervezett felemelése 1918-ban. ； Idem: 1918 forró nyara és a Magyar Királyi Csendőrség. ; Idem: A Magyar Királyi Csendőrség és a vasútbiztonság 1917-1918. ; Idem: A császári csendőrség tiszti kara 1849-1868. ; Idem: A Magyar Királyi Csendőrség és a terület-visszacsatolások. ; SzAKÁLY: Néhány gondolat a volt Magyar Királyi Csendőrségről. ; Idem: A két világháború közötti rendvédelmi szervek tevékenységének néhány jellemzője. ; Idem: A Magyar Királyi Csendőrség az első központosított magyar közbiztonsági örtestület. ; Idem: Az Osztrák-Magyar Monarchia hadseregének tábori csendőrsége (Rövid áttekintés). ; Idem: A Magyar Királyi Csendőrség 1919-1941. ; Idem: Akik a Magyar Királyi Csendőrséget — 1938 és 1945 között — vezették. ; SzELEI ; SzŰCS ; TAMÁSKA ; VARRÓ: Rádió közvetítés az ungvári csendőr iskolából. „Székely fiúkból nevelik a magyar csendőröket” közvetítés az ungvári csendőr iskolából. ; Idem: Hatvan éves a Magyar Királyi Csendőrség. ; VEDÓ: A Magyar Királyi Csendőrség karhatalmi tevékenységének szabályozása a dualizmus idején. ; Idem: Rádió a Magyar Királyi Csendőrség szolgálatában. ; Idem: A Magyar Királyi Csendőrség karhatalmi fellépésének gyakorlata. ; Idem: A haderő karhatalmi tevékenysége 1867-1918. ; Idem: A Francia Nemzeti Csendőrség a két világháború kÖZÖtt. ; ZACHAR ; ZEIDLER ; ZÉTÉNYI

A periodika első 42 számában a Magyar Királyi Csendőrség története témakörében összesen 39 szerző tollából 91 tanulmány jelent meg.

${ }^{11}$ A ,, Csendőrségi Lapok” a Magyar Királyi Csendőrség kiadványa volt, amely a csendőrökröl a csendőröknek és a nagyközönségnek szólt. A lap önfenntartó volt. Valamennyi szervezeti egység előfizetett a folyóiratra. Szerkesztői csendőrtisztek voltak. A lap a testület életében fontos szerepet töltött be, például a csendörségi szolgálat tipikus szituációit közölte a szerkesztőség a lap hasábjain, amelyeket az őrsök személyi állomány megvitatott és az így született megoldásokat a szerkesztőséggel megosztotta, amely a legkiválóbbakat elismerte. Ily módon biztosítva volt, hogy a leggyakrabban előforduló szolgálati szituációkkal a személyi állomány lényegében folyamatosan foglalkozzon. A folyóirat kettő, illetve három hetenként jelent meg. Az első évfolyamot 1907-ben adták ki. 1920 és 1923 között a periodika szünetelt. 1924-ben — folytatólagosan — került sor a XXIV. évfolyam publikálására. Az utolsó évfolyamot, a XXXIV. évfolyamot 1944-ben adták ki. Mivel a periodika a testületi élet mindennapjaival foglalkozott a folyóiratban közölt cikkek ma már a testület történetének pótolhatatlan dokumentumai.

${ }^{12}$ A Magyar Királyi Csendőrségre vonatkozó nem nagy számú törvény a Corpus Juris-ban található. A testület történetének a feltárása tekintetében pedig elengedhetetlen a rendeletek feldolgozása, mert ezek tartalmazzák a testület múködése szabályozásának rendkívül fontos részleteit. A testületre vonatkozó fontosabb rendeleteket a Magyarországi Rendeletek Tára-nak és a Belügyi Közlöny-nek az évfolyamai tartalmazzák. Emellett azonban — mivel a testület személyi állományának tagjai katonának minősültek — a személyügyi döntések a Honvédségi Közlöny személyi ügyeket tartalmazó részében jelentek meg. Emellett külön Csendőrség Közlöny is megjelent, amely a testülettel kapcsolatos legrészletesebb információkat tartalmazza. A testületi közlöny első évfolyamát 1912-ben adták ki. Ezt követően az évfolyamok folyamatosak 1918-al bezárólag. Az 1919. évfolyam csonka. 1924-ben — a IX. évfolyammal - folytatódott a közlöny. Ezt követően az évfolyamok ugyancsak folyamatosan kerültek kiadásra. Az utolsó közölt évfolyam az 1944. évi XXVIII. évfolyam. 
13 A Magyar Királyi Csendőrség tevékenységét általában és a testület különböző szervezeti egységtípusait, illetve a szaktevékenységeket külön szabályzatok szabályozták. A testület fennállása során — a testület egészére vonatkozóan — több szolgálati utasítást is kiadtak. Ezek voltak:

SZUT-1881 ; SZUT-1887 ; SZUT-1896 ; SZUT-1903 ; SZUT-1912 ; SZUT-1927 ; SZUT-1941.

Összesen a testületi szabályzókból 87 szabályzat maradt fenn, amelyek a nyomozó munkától a becsületügyi szabályozáson keresztül egészen a nősülésig szabályozták a szervezet és személyi állománya teendőit. 1898-ban külön kimutatás is készült a szabályzatokról.

Kimutatás a szolgálati könyvekröl, szabályokról és utasitásokról a Magyar Királyi Honvédség, a népfölkelés és a csendörség számára.

A testületnél a szabályzatokat folyamatosan nyilvántartották, azokról naprakész jegyzékkel rendelkeztek. Ezen túlmenően pedig a testületre vonatkozó rendeletekről jogszabálygyüjteményeket készítettek, amelyeket folyamatosan aktualizáltak.

A közbiztonsági tevékenység lényegét a megvalósítás legcélravezetőbb módjait különböző tansegédlet jellegü kiadványok értelmezték, magyarázták, a legrészletesebben.

Úmutató a csendör járörök részére.

${ }^{14}$ ZACHAR: Fejezetek az osztrák csendőrség történetéből 1849-1918. op.cit.

${ }^{15}$ Idem: A HABSBURG-hatalom és a magyar rendvédelem.

${ }^{16}$ Az erdélyi és a horvátországi csendőr ezredeket a magyar kormány 1876-ban átvette a közös haderőtől, azonban a Magyar Szent Korona alá tartozó teljes vidéki területekre kiterjedően az országos csendőr szervezet felállítására 1881-ben került sor a Magyar Királyi Csendőrség létrehozásával. A testület teljes kiépítése pedig csaknem 1/2 évtized alatt valósult meg.

1881/II.tc. ; 1881/III.tc.

${ }^{17}$ PARÁDI József: A Magyar Királyi Csendőrség szervezete. op.cit.

${ }^{18}$ Idem: A Magyar Királyi Csendörség. Az elsö magyar polgári, központositott, közbiztonsági örtestület 1881-1945. op.cit.

${ }^{19}$ CsAPÓ: A Magyar Királyi Csendörség története 1881-1914. op.cit. 42.p.

${ }^{20}$ PRESZLY: op.cit. 41-105.p.

${ }^{21}$ PARÁDI József: A Magyar Királyi Csendőrség szervezete. op.cit.

$221882 / X . t c$

${ }^{23}$ Felhívással a közigazgatási hatóságok, bíróságok, ügyészségek, adóhivatalok fordultak az őrsökhöz „karhatalom” vagy „rendőri segély” igényléséért. Megkereséssel a csendőrség tiszti parancsnokságai irányába éltek a jelentősebb ügyekben. NÉMETHY: 107-138.p.

${ }^{24}$ Próbacsendörök tankönyve kérdések és feleletekben feldolgozva.

${ }^{25}$ ВЕӦTHY

${ }^{26}$ SZUT-1881. op.cit.

${ }^{27}$ Az 1887 és 1888, majd 1889-ben Szervezeti és szolgálati utasitás a Magyar Királyi Csendörség számára címmel kiadott szolgálati szabályzat második fó fejezetének módosított változata, melyet 1900-ban Budapesten a Pesti Nyomda adott ki. SZUT-1887: op.cit. 28.§

${ }^{28}$ CSAPÓ: A Magyar Királyi Csendörség története 1881-1914. op.cit. 34.p.

${ }^{29}$ SOLTÉSZ

${ }^{30}$ PARÁDI József: A Magyar Királyi Csendörség. Az elsö magyar polgári, központositott közbiztonsági örtestület 1881-1945. op.cit. 94.p.

${ }^{31}$ KAISER: Az örs mindennapi élete. op.cit.

${ }^{32} \mathrm{~S}$. százados

${ }^{33}$ ANIK

${ }^{34}$ FORRÓ: A csendőr kerület rendvédelmi tevékenységének értékelése. op.cit.

${ }^{35}$ PARÁDI József: A Magyar Királyi Csendőrség megalakulása és müködése 1881-1918. op.cit.

${ }^{36}$ CsAPÓ: A Magyar Királyi Csendörség története 1881-1914. op.cit. 31.p.

${ }^{37}$ Laktanya-szabályok a Magyar Királyi Csendőrség számára.

${ }^{38}$ KAISER: Az örs mindennapi élete. op.cit. 47.p.

${ }^{39}$ REKTOR: op.cit. 509.p.

${ }^{40}$ Útmutató a csendör járőrök részére. op.cit.

${ }^{41}$ Próbacsendörök tankönyve kérdések és feleletekben feldolgozva. 25-41.p. op.cit.

\section{Jegyzetekben alkalmazott röviditések:}

\section{MONOGRÁFIÁK, KISMONOGRÁFIÁK ÉS HASONLÓ JELLEGÜ KÖTETEK}

CSAPÓ: A Magyar Királyi Csendőrség története 1881-1914.

(9.;19.;28.;36.;)

KAISER: A Magyar Királyi Csendőrség története a két világháború között.

(9.;)

PARÁDI: A Magyar Királyi Csendörség Az elsö magyar polgári, központositott közbiztonsági örtestület 1881-1945. $(9 . ; 18 . ; 30 . ;)$
CsAPÓ Csaba: A Magyar Királyi Csendörség története 1881-1914. Pécs, 1999, Pro Pannónia Kiadói Alapítvány. 186 p. HU-ISBN 9639079405. /Pannónia Könyvek./ HU-ISSN 0237-4277.

KAISER Ferenc: A Magyar Királyi Csendörség története a két világháború között. Pécs, 2002, Pro Pannónia Kiadó Alapítvány. 175 p. HU-ISBN 963907982 0. /Pannónia Könyvek/ HU-ISSN 0237-4277.

PARÁDI József: A Magyar Királyi Csendörség. Az elsö magyar polgári, központositott közbiztonsági örtestület 1881-1945. Budapest, 2012, Szemere Bertalan Magyar Rendvédelem-történeti Tudományos Társaság. 281 p. HU-ISBN 978963084794 0. /A magyar rendvédelem-történet öröksége, 2./ HU-ISSN 2062-8447.

PRESZLY Lóránd: A magyar Királyi Csendörség története 1881-1919. Budapest, 1920, Honvédelmi Sajtóvállalat. 142 p. 
REKTOR

$(6 . ; 9 ; 39 . ;)$

SZAMEL

(1.;)

\section{TANKÖNYVEK - TANSEGÉDLETEK}

PARÁDI: A magyar rendvédelem története

(2.;)

Próbacsendörök tankönyve kérdések és feleletekben feldolgozva.

(24.;41.;)

Úmutató a csendőr járőrök részére. (13.;40.;

\section{TANULMÁNYOK}

ARTNER: Egy közbiztonsági örtestület útja Párizstól - Itálián és Ausztrián keresztül - Budapestig.

(10.;)

ARTNER: A Magyar Királyi Csendőrség és a városok.

(10.;)

ARTNER: Az osztrák csendőrség 1848-

1938.

(10.;)

ARTNER: A bajor csendőrség a XX. század húszas éveiben.

(10.;)

Artner - PARÁdi - Zeidler: A Magyar Királyi Csendőrség légi, vízi, vasúti és közúti szakszolgálati ágai. (10.;)

BACSA

(10.;)

BoDA

(10.;)

CSAPÓ: A Magyar Királyi Csendörség fegyverhasználati jogáról 1881-1914. (10.;)

CSAPÓ: A csendőrség és a városok 18811914.

(10.;)
ReKToR Béla: A Magyar Királyi Csendörség oknyomozó története. Cleveland, Ohio, USA, 1980, Árpád Könyvkiadó Vállalat. 552 p. USAISBN 0934214018 .

SzAMEL Lajos: A rendészet és a rendőrség jogi szabályozásának elméleti alapjai. Budapest, 1990, Magyar Tudományos Akadémia Államtudományi Kutatások Programirodája. 98 p. HU-ISBN 9637450378.

PARÁDI József et al. (szerk.): A magyar rendvédelem története. Budapest, 1996, Osiris, 367 p. HU-ISBN 9630479583.

Próbacsendörök tankönyve kérdések és feleletekben feldolgozva. Budapest, s.a. (cc. Első világháború előtt), Kaufman Ábrahám és társai. 103 p.

Úmutató a csendőr járőrök részére. Máramarossziget, 1908, Kaufman Ábrahám és Társai. 57 p. (A 2. és 3. kiadás Budapest, 1909, 1913, ugyanazon kiadónál.)

ARTNER Ramona: Egy közbiztonsági örtestület útja Párizstól — Itálián és Ausztrián keresztül - Budapestig. Rendvédelem-történeti Füzetek (Acta Historiae Praesidii Ordinis), XXII.évf. (2012) 26.sz. 13-18.p. HU-ISSN 1216-6774.

ARTNER Ramona: A Magyar Királyi Csendőrség és a városok. Rendvédelem-történeti Füzetek (Acta Historiae Praesidii Ordinis), XXIII.évf. (2013) 27-28-29-30.sz. 13-22.p. HU-ISSN 1216-6774.

ARTNER Ramona: Az osztrák csendörség 1848-1938. Rendvédelem-történeti Füzetek (Acta Historiae Praesidii Ordinis), XXIV.évf. (2014) 39-40-4142.sz. 15-22.p. HU-ISSN 1216-6774.

ARTNER Ramona: A bajor csendőrség a XX. század húszas éveiben. Rendvédelem-történeti Füzetek (Acta Historiae Praesidii Ordinis), XXIV.évf. (2014) 39-40-41-42.sz. 23-30.p. HU-ISSN 1216-6774.

ARTNER Ramona — PARÁDI József — ZEIDLER Sándor: A Magyar Királyi Csendőrség légi, vízi, vasúti és közúti szakszolgálati ágai. Rendvédelemtörténeti Füzetek (Acta Historiae Praesidii Ordinis), XXIII.évf. (2013) 2728-29-30.sz. 23-40.p. A tanulmány korábbi változata 2013. február 15-én, Budapesten hangzott el a Szemere Bertalan Magyar Rendvédelem-történeti Tudományos Társaság Csendőrségtörténeti Szakosztálya által szervezett közbiztonság-történeti tudományos szimpozion-sorozatnak. „A XIX-XX. századi magyarországi csendörségek” címü XIII. szimpozionján. A publikált tanulmány az előadás javított, bővített és átdolgozott változata.

BACSA Gábor: A csendörség részvétele Zala-megye határörizetében. Rendvédelem-történeti Füzetek (Acta Historiae Praesidii Ordinis), VII. évf. (1997) 8.sz. 5-11.p. HU-ISSN 1216-6774. A tanulmány korábbi változata 1996. október 29-én, Budapesten hangzott el a Szemere Bertalan Magyar Rendvédelem-történeti Tudományos Társaság által szervezett rendvédelem-történeti tudományos konferencia-sorozatnak. „A napóleoni közbiztonsági örtestület útja Párizstól — Itálián és Ausztrián keresztül —Budapestig" című VIII. konferenciáján. A publikált tanulmány az előadás javított, bővített és átdolgozott változata.

BoDA József: Az Európai Csendőri Erő, avagy egy új békefenntartó alakulat születése. Rendvédelem-történeti Füzetek (Acta Historiae Praesidii Ordinis), XXI. évf. (2011) 24.sz. 13-19.p.HU-ISSN 1216-6774.

CSAPÓ Csaba: A Magyar Királyi Csendőrség fegyverhasználati jogáról 1881-1914. Rendvédelem-történeti Füzetek (Acta Historiae Praesidii Ordinis), VII.évf. (1997) 8.sz. 12-16.p. HU-ISSN 1216-6774. A tanulmány korábbi változata 1996. október 29-én, Budapesten hangzott el a Szemere Bertalan Magyar Rendvédelem-történeti Tudományos Társaság által szervezett rendvédelem-történeti tudományos konferencia-sorozatnak. „A napóleoni közbiztonsági örtestület útja Párizstól - Itálián és Ausztrián keresztül - Budapestig" címü VIII. konferenciáján. A publikált tanulmány az előadás javított, bővített és átdolgozott változata.

CsAPÓ Csaba: A csendőrség és a városok 1881-1914. Rendvédelemtörténeti Füzetek (Acta Historiae Praesidii Ordinis), X.évf. (2000) 12.sz. $43-$ 48.p. HU-ISSN 1216-6774. A tanulmány korábbi változata 1999. október 6án, Budapesten hangzott el a Szemere Bertalan Magyar Rendvédelemtörténeti Tudományos Társaság által szervezett rendvédelem-történeti tudo- 
CSAPÓ: Erdély csendörsége az átmenet _ éveiben 1867-1881.

(10.;)

CSÓKA

(10;)

DAvola: A Magyar Királyi Csendőrség _ határörizeti feladatai 1912-ben. (10.;)

DAVOLA: A tábori csendőrség, mint a katonai rendőrség elődje. (10.;)

DAvolA: Fényképezés a Magyar Királyi Csendőrségnél. (10.;)

ERNYES

FAZEKAS

(10.;)

FORRÓ: A csendőrség története. A csendör örs.

(10.;) mányos konferencia-sorozatnak. „A közigazgatás, a véderő és a rendvédelem kapcsolatának változásai a polgári magyar állam időszakában." címü XII. konferenciáján. A publikált tanulmány az előadás javított, bövített és átdolgozott változata.

CsAPÓ Csaba: Erdély csendőrsége az átmenet éveiben 1867-1881. Rendvédelem-történeti Füzetek (Acta Historiae Praesidii Ordinis), XXII. évf. (2012) 25.sz. 27-31.p. HU-ISSN 1216-6774. A tanulmány korábbi változata 2010. december 6-án, Budapesten hangzott el a Szemere Bertalan Magyar Rendvédelem-történeti Tudományos Társaság által szervezett rendvédelem-történeti tudományos konferencia-sorozatnak. „A közbiztonság közös Kárpát-medence-i örökségünk.” címü XXV. konferenciáján. A publikált tanulmány az előadás javított, bővített és átdolgozott változata.

CsóKA Ferenc: Csendőrség és hírszerzés 1930-1945. Rendvédelem-történeti Füzetek (Acta Historiae Praesidii Ordinis), VII. évf. (1997) 8.sz. 1720.p. HU-ISSN 1216-6774. A tanulmány korábbi változata 1996. október 29-én, Budapesten hangzott el a Szemere Bertalan Magyar Rendvédelemtörténeti Tudományos Társaság által szervezett rendvédelem-történeti tudományos konferencia-sorozatnak. „A napóleoni közbiztonsági örtestület útja Párizstól - Itálián és Ausztrián keresztül-Budapestig” címü VIII. konferenciáján. A publikált tanulmány az előadás javított, bővített és átdolgozott változata.

DAvola József: A Magyar Királyi Csendőrség határörizeti feladatai 1912ben. Rendvédelem-történeti Füzetek (Acta Historiae Praesidii Ordinis), X.évf. (2000) 11.sz. 21-23.p.HU-ISSN 1216-6774. A tanulmány korábbi változata 1999. április 20-án, Budapesten hangzott el a Szemere Bertalan Magyar Rendvédelem-történeti Tudományos Társaság által szervezett rendvédelem-történeti tudományos konferencia-sorozatnak. „Szabad mozgás a Kárpát-medencében” címü XI. konferenciáján. A publikált tanulmány az előadás javított, bővített és átdolgozott változata.

DAvola József: A tábori csendőrség, mint a katonai rendőrség elődje. Rendvédelem-történeti Füzetek (Acta Historiae Praesidii Ordinis), X.évf. (2000) 12.sz. 19-54.p. HU-ISSN 1216-6774. A tanulmány korábbi változata 1999. október 6-án, Budapesten hangzott el a Szemere Bertalan Magyar Rendvédelem-történeti Tudományos Társaság által szervezett rendvédelem-történeti tudományos konferencia-sorozatnak. „A közigazgatás, a véderö és a rendvédelem kapcsolatának változásai a polgári magyar állam időszakában” címü XII. konferenciáján. A publikált tanulmány az előadás javított, bővített és átdolgozott változata.

DAvola József: Fényképezés a Magyar Királyi Csendőrségnél. Rendvédelem-történeti Füzetek (Acta Historiae Praesidii Ordinis), XXI.évf. (2011) 24.sz. 18-22.p. HU-ISSN 1216-6774. A tanulmány korábbi változata 2009. december 3-án, Budapesten hangzott el a Szemere Bertalan Magyar Rendvédelem-történeti Tudományos Társaság által szervezett rendvédelem-történeti tudományos konferencia-sorozatnak. „Csendörség AusztriaMagyarországon, illetve Ausztriában és Magyarországon 1849-2005. ” címü XXIV. konferenciáján. A publikált tanulmány az előadás javított, bővített és átdolgozott változata.

ERNYES Mihály: Pandúrság helyett csendörség Baranyában. Rendvédelemtörténeti Füzetek (Acta Historiae Praesidii Ordinis), VII.évf. (1997) 8.sz. 27-33.p. HU-ISSN 1216-6774. A tanulmány korábbi változata 1996. október 29-én, Budapesten hangzott el a Szemere Bertalan Magyar Rendvédelemtörténeti Tudományos Társaság által szervezett rendvédelem-történeti tudományos konferencia-sorozatnak. „A napóleoni közbiztonsági örtestület útja Párizstól - Itálián és Ausztrián keresztül - Budapestig” címü VIII. konferenciáján. A publikált tanulmány az előadás javított, bővitett és átdolgozott változata.

FAZEKAS Csaba: A csendőrség és a történelmi egyházak kapcsolata a Horthy korszakban az el nem ismert felekezetek kezelése tükrében. Rendvédelemtörténeti Füzetek (Acta Historiae Praesidii Ordinis), VII.évf. (1997) 8.sz. 34-40.p. HU-ISSN 1216-6774. A tanulmány korábbi változata 1996. október 29-én, Budapesten hangzott el a Szemere Bertalan Magyar Rendvédelemtörténeti Tudományos Társaság által szervezett rendvédelem-történeti tudományos konferencia-sorozatnak. „A napóleoni közbiztonsági őrtestület útja Párizstól - Itálián és Ausztrián keresztül - Budapestig" címü VIII. konferenciáján. A publikált tanulmány az előadás javított, bővített és átdolgozott változata.

FORRÓ János: A csendőrség története. A csendör örs. Rendvédelem-történeti Füzetek (Acta Historiae Praesidii Ordinis), III. évf. (1993) 4.sz. 132-151.p. HU-ISSN 1216-6774. A tanulmány korábbi változata 1992. szeptember 29én, Budapesten hangzott el a Szemere Bertalan Magyar Rendvédelem- 
FORRÓ: A csendör kerület rendvédelmi _ tevékenységének értékelése. $(10 . ; 34 . ;))$

FORRÓ: A székesfehérvári csendőrkerület teendői a vagyon elleni büncselekmények megelőzésében és felderítésében. (10.;)

FORRÓ: A székesfehérvári csendőrkerület kapcsolata a közigazgatással. (10.;)

FORRÓ: Csendőrségtörténeti kutatásaim tapasztalatai.

FORRÓ: A polgári magyar állam központosított közbiztonsági örtestületének közrendvédelmi szolgálata. (10.;)

FORRÓ: A Magyar Királyi Csendőrség és a Fejér vármegyei zsidó deportálás. (10.;)

FORRÓ: A székesfehérvári csendőr kerület küzdelme Fejér vármegye közbiztonságáért 1884-1945.

(10.;) történeti Tudományos Társaság által szervezett rendvédelem-történeti tudományos konferencia-sorozatnak. „A dualista Magyarország rendvédelme” címủ IV. konferenciáján. A publikált tanulmány az előadás javított, bővített és átdolgozott változata.

FORRÓ János: A csendőr kerület rendvédelmi tevékenységének értékelése. Rendvédelem-történeti Füzetek (Acta Historiae Praesidii Ordinis), VII. évf. (1997) 8.sz. 41-45.p. HU-ISSN 1216-6774. A tanulmány korábbi változata 1996. október 29-én, Budapesten hangzott el a Szemere Bertalan Magyar Rendvédelem-történeti Tudományos Társaság által szervezett rendvédelem-történeti tudományos konferencia-sorozatnak. ,A napóleoni közbiztonsági örtestület útja Párizstól — Itálián és Ausztrián keresztül — Budapestig" című VIII. konferenciáján. A publikált tanulmány az előadás javított, bővített és átdolgozott változata.

FORRÓ János: A székesfehérvári csendőrkerület teendői a vagyon elleni büncselekmények megelözésében és felderítésében. Rendvédelem-történeti Füzetek (Acta Historiae Praesidii Ordinis), VIII. évf. (1998) 9.sz. 32-38.p. HU-ISSN 1216-6774. A tanulmány korábbi változata 1997. szeptember 22én, Budapesten hangzott el a Szemere Bertalan Magyar Rendvédelemtörténeti Tudományos Társaság által szervezett rendvédelem-történeti tudományos konferencia-sorozatnak. „Gazdasági rendvédelmünk a XIX$X X$. században" címü IX. konferenciáján. A publikált tanulmány az előadás javított, bővített és átdolgozott változata.

FORRÓ János: A székesfehérvári csendőrkerület kapcsolata a közigazgatással. Rendvédelem-történeti Füzetek (Acta Historiae Praesidii Ordinis), X. évf. (2000) 12.sz. 58-61.p. HU-ISSN 1216-6774. A tanulmány korábbi változata 1999. október 6-án, Budapesten hangzott el a Szemere Bertalan Magyar Rendvédelem-történeti Tudományos Társaság által szervezett rendvédelem-történeti tudományos konferencia-sorozatnak. „A közigazgatás, a véderö és a rendvédelem kapcsolatának változásai a polgári magyar állam időszakában” címü XII. konferenciáján. A publikált tanulmány az előadás javított, bővített és átdolgozott változata.

FORRÓ János: Csendőrségtörténeti kutatásaim tapasztalatai. Rendvédelemtörténeti Füzetek (Acta Historiae Praesidii Ordinis), XVII. évf. (2009) 20.sz. 38-43.p. HU-ISSN 1216-6774. A tanulmány korábbi változata 2006. szeptember 29-én, Budapesten hangzott el a Szemere Bertalan Magyar Rendvédelem-történeti Tudományos Társaság által szervezett rendvédelem-történeti tudományos konferencia-sorozatnak. „A XIX-XX. századi magyar forradalmak hatása a nemzeti rendvédelmi rendszerünkre" címü XX. konferenciáján. A publikált tanulmány az elöadás javított, bővített és átdolgozott változata.

FORRÓ János: A polgári magyar állam központosított közbiztonsági őrtestületének közrendvédelmi szolgálata. Rendvédelem-történeti Füzetek (Acta Historiae Praesidii Ordinis), XIX. évf. (2010) 22.sz. 46-52.p. HU-ISSN 1216-6774. A tanulmány korábbi változata 2008. október 10-én, Budapesten hangzott el a Szemere Bertalan Magyar Rendvédelem-történeti Tudományos Társaság által szervezett rendvédelem-történeti tudományos konferencia-sorozatnak. „,Másfél évszázad rendszerváltozásainak hatásai nemzeti rendvédelmünkre" címü XXII. konferenciáján. A publikált tanulmány az előadás javított, bővített és átdolgozott változata.

FORRÓ János: A Magyar Királyi Csendőrség és a Fejér vármegyei zsidó deportálás. Rendvédelem-történeti Füzetek (Acta Historiae Praesidii Ordinis), XXI. évf. (2011) 24.sz. 23-31.p. HU-ISSN 1216-6774. A tanulmány korábbi változata 2009. december 3-án, Budapesten hangzott el a Szemere Bertalan Magyar Rendvédelem-történeti Tudományos Társaság által szervezett rendvédelem-történeti tudományos konferencia-sorozatnak. „Csendörség Ausztria-Magyarországon illetve Ausztriában és Magyarországon 1848-2005” címü XXIV. konferenciáján. A publikált tanulmány az előadás javított, bővített és átdolgozott változata.

FoRRÓ János: A székesfehérvári csendőr kerület küzdelme Fejér vármegye közbiztonságáért 1884-1945. Rendvédelem-történeti Füzetek (Acta Historiae Praesidii Ordinis), XXI. évf. (2011) 24.sz. 32-72.p. HU-ISSN 1216-6774. A tanulmány korábbi változata 2009. december 3-án, Budapesten hangzott el a Szemere Bertalan Magyar Rendvédelem-történeti Tudományos Társaság által szervezett rendvédelem-történeti tudományos konferencia-sorozatnak. „Csendőrség Ausztria-Magyarországon illetve Ausztriában és Magyarországon 1848-2005" című XXIV. konferenciáján. A publikált tanulmány az előadás javított, bővített és átdolgozott változata. 
FORRÓ: A magyar csendőrség KeletDunántúl román megszállásakor. $(10 . ;)$

GEBHARDT: Die Österreichische Gendarmerie in XX. Jahrhundert. [Az osztrák csendőrség a XX. században.]

$(10 . ;)$

GEBHARDT: Die miliärische Organisation der Österreichischen Gendarmerie von 1849 bis 1918. [A katonailag szervezett osztrák csendőrség 1849-től 1918-ig.] (10.;)

HEGEDÜs: A Magyar Királyi Csendőrség harc- és gépjárművei.

(10.;)

HEGEDÜS - FRÖCHLICH: Forgópisztolyok a honvéd lovasságnál és a Magyar Királyi Csendőrség lovas szervezeti elemeinél.

(10.;)

HeszTERA: Die Kommandostrukturen der Gendarmerie von 1850 bis 1993. [A csendőrség parancsnoksági rendszere 1850-1993 között.]

(10.;)

ILLÉSFALVI

$(10 . ;)$

KAISER: Az örs mindennapi élete.

(10.;31.;38.;)
FORRÓ János: A magyar csendőrség Kelet-Dunántúl román megszállásakor. Rendvédelem-történeti Füzetek (Acta Historiae Praesidii Ordinis), XXIV.évf. (2014) 39-40-41-42.sz. 31-42.p. HU-ISSN 1216-6774. A tanulmány korábbi változata 2014. X. 17-én, Budapesten hangzott el a Szemere Bertalan Magyar Rendvédelem-történeti Tudományos Társaság által szervezett rendvédelem-történeti tudományos konferencia-sorozatnak. „, A kivételes hatalom és a rendvédelem" címü XXX. konferenciáján. A publikált tanulmány az előadás javított, bővített és átdolgozott változata.

GeBHARDT Helmut: Die Österreichische Gendarmerie in XX. Jahrhundert. [Az osztrák csendőrség a XX. században.] Rendvédelem-történeti Füzetek (Acta Historiae Praesidii Ordinis), IX.évf. (1999) 10.sz. 53-58.p. HU-ISSN 1216-6774. A tanulmány korábbi változata 1998. IX. 22-én, Budapesten hangzott el a Szemere Bertalan Magyar Rendvédelem-történeti Tudományos Társaság által szervezett rendvédelem-történeti tudományos konferencia-sorozatnak. „A nyugati rendvédelem hatása a XIX-XX. századi magyar rendvédelemre" címü X. konferenciáján. A publikált tanulmány az előadás javított, bővített és átdolgozott változata.

GEBHARDT Helmut: Die miliärische Organisation der Österreichischen Gendarmerie von 1849 bis 1918. [A katonailag szervezett osztrák csendőrség 1849-töl 1918-ig.] Rendvédelem-történeti Füzetek (Acta Historiae Praesidii Ordinis), X.évf. (2000) 12.sz. 62-64.p. HU-ISSN 1216-6774. A tanulmány korábbi változata 1999. október 6-án, Budapesten hangzott el a Szemere Bertalan Magyar Rendvédelem-történeti Tudományos Társaság által szervezett rendvédelem-történeti tudományos konferencia-sorozatnak. „A közigazgatás, a véderö és a rendvédelem kapcsolatának változásai a polgári magyar állam idöszakában” címü XII. konferenciáján. A publikált tanulmány az előadás javított, bővített és átdolgozott változata.

HEGEDŰs Ernő: A Magyar Királyi Csendőrség harc- és gépjárművei. Rendvédelem-történeti Füzetek (Acta Historiae Praesidii Ordinis), XXIII.évf. (2013) 27-28-29-30.sz. 89-100.p. HU-ISSN 1216-6774. A tanulmány korábbi változata 2012. október 27-én, Budapesten hangzott el a Szemere Bertalan Magyar Rendvédelem-történeti Tudományos Társaság által szervezett rendvédelem-történeti tudományos konferencia-sorozatnak. „A XIX-XX. századi magyar állam nemzetbiztonsági testületei” címü XXVII. konferenciáján. A publikált tanulmány az előadás javított, bővített és átdolgozott változata.

HEGEDÜs Ernő - FRÖCHLICH Dávid: Forgópisztolyok a honvéd lovasságnál és a Magyar Királyi Csendőrség lovas szervezeti elemeinél. Rendvédelemtörténeti Füzetek (Acta Historiae Praesidii Ordinis), XXIV.évf. (2014) 3940-41-42.sz. 43-50.p. HU-ISSN 1216-6774. A tanulmány korábbi változata 2014. október 17--én, Budapesten hangzott el a Szemere Bertalan Magyar Rendvédelem-történeti Tudományos Társaság által szervezett rendvédelem-történeti tudományos konferencia-sorozatnak. „, A kivételes hatalom és a rendvédelem" címü XXX. konferenciáján. A publikált tanulmány az előadás javított, bővített és átdolgozott változata.

HESZTERA Franz: Die Kommandostrukturen der Gendarmerie von 1850 bis 1993. [A csendörség parancsnoksági rendszere 1850-1993 között.] Rendvédelem-történeti Füzetek (Acta Historiae Praesidii Ordinis), IV. évf. (1994) 5.sz. 18-35.p. HU-ISSN 1216-6774. A tanulmány korábbi változata 1993. szeptember 21-én, Budapesten hangzott el a Szemere Bertalan Magyar Rendvédelem-történeti Tudományos Társaság által szervezett rendvédelem-történeti tudományos konferencia-sorozatnak. „Háború, forradalom trianon” címü V. konferenciáján. A publikált tanulmány az előadás javított, bővített és átdolgozott változata.

ILLÉSFALVI Péter: A németek által megszállt Bánság helyzete 1941-ben, a Magyar Királyi Csendőrség Központi Nyomozó Parancsnokságának jelentései alapján. Rendvédelem-történeti Füzetek (Acta Historiae Praesidii Ordinis), XIV. évf. (2008) 17.sz. 19-25.p. HU-ISSN 1216-6774. A tanulmány korábbi változata 2003. november 11-én, Budapesten hangzott el a Szemere Bertalan Magyar Rendvédelem-történeti Tudományos Társaság által szervezett rendvédelem-történeti tudományos konferencia-sorozatnak. „A rendvédelem humán viszonyai" című XVII. konferenciáján. A publikált tanulmány az előadás javított, bővített és átdolgozott változata.

KAISER Ferenc: Az őrs mindennapi élete. Rendvédelem-történeti Füzetek (Acta Historiae Praesidii Ordinis) VII.évf. (1998) 8.sz. 46.p. HU-ISSN 1216-6774 
KAISER: A csendőr őrs gazdaságvédelemmel kapcsolatos feladatai a két világháború között.

(10.;)

KÁLMÁN: A Magyar Királyi Csendőrség tevékenysége Somogy vármegyében a megalakulástól 1903-ig.

(10.;)

KÁLMÁN: Somogy vármegye bünüldözési tapasztalatai a kiegyezéstől a I. vh-ig. (10.;)

KESERŰ: Rendőrség és csendőrség Magyarország hadbalépésétől a hadműveletek befejezéséig.

(10.;)

KESERŰ: A Magyar Királyi Csendőrség a második világháború hadműveleteiben. (10.;)

KISS Gábor: Csendőrök az emigrációban. (10.;)

KIss István Géza: A Magyar Királyi csendőrség hagyományai, muzeális emlékanyagainak őrzési helyei hazánkban és külföldön.

(10.;)

KOMÁROMI

(10.;)
KAISER Ferenc: A csendőr őrs gazdaságvédelemmel kapcsolatos feladatai a két világháború között. Rendvédelem-történeti Füzetek (Acta Historiae Praesidii Ordinis), VIII.évf. (1998) 9.sz. 39-44.p. HU-ISSN 1216-6774. A tanulmány korábbi változata 1997. szeptember 22-én Budapesten hangzott el a Szemere Bertalan Magyar Rendvédelem-történeti Tudományos Társaság által szervezett rendvédelem-történeti tudományos konferencia-sorozatnak. „Gazdasági rendvédelmünk a XIX-XX. században.” címü IX. konferenciáján. A publikált tanulmány az előadás javított, bővített és átdolgozott változata.

KÁLMÁN Zsolt: A Magyar Királyi Csendőrség tevékenysége Somogy vármegyében a megalakulástól 1903-ig. Rendvédelem-történeti Füzetek (Acta Historiae Praesidii Ordinis), XIV. évf. (2008) 17.sz. 26-36.p. HU-ISSN 12166774. A tanulmány korábbi változata 2003. november 11-én Budapesten hangzott el a Szemere Bertalan Magyar Rendvédelem-történeti Tudományos Társaság által szervezett rendvédelem-történeti tudományos konferencia-sorzatnak. „A rendvédelem humán viszonyai.” címü XVII. konferenciáján. A publikált tanulmány az előadás javított, bővített és átdolgozott változata.

KÁLMÁN Zsolt: Somogy vármegye bünüldözési tapasztalatai a kiegyezéstől a I. vh-ig. Rendvédelem-történeti Füzetek (Acta Historiae Praesidii Ordinis), XVI. évf. (2009) 19.sz. 60-63.p. HU-ISSN 1216-6774. A tanulmány korábbi változata 2005. október 6-án, Budapesten hangzott el a Szemere Berta-lan Magyar Rendvédelem-történeti Tudományos Társaság által szervezett rendvédelem-történeti tudományos konferencia-sorzatnak. „Másfél évtized nemzeti rendvédelem-történetünk kutatásának szolgálatában." címü XIX. konferenciáján. A publikált tanulmány az előadás javított, bővített és átdolgozott változata.

KESERŰ István: Rendőrség és csendőrség Magyarország hadbalépésétől a hadműveletek befejezéséig. Rendvédelem-történeti Füzetek (Acta Historiae Praesidii Ordinis), VI. évf. (1996) 7.sz. 35-45.p. HU-ISSN 1216-6774. A tanulmány korábbi változata 1995. október 25-én, Budapesten hangzott el a Szemere Bertalan Magyar Rendvédelem-történeti Tudományos Társaság által szervezett rendvédelem-történeti tudományos konferencia-sorzatnak. „Háborúból diktatúrába” címü VII. konferenciáján. A publikált tanulmány az előadás javított, bővített és átdolgozott változata.

KESERŰ István: A Magyar Királyi Csendőrség a második világháború hadműveleteiben. Rendvédelem-történeti Füzetek (Acta Historiae Praesidii Ordinis), VII. évf. (1997) 8.sz. 57-59.p. HU-ISSN 1216-6774. A tanulmány korábbi változata 1996. október 29-én, Budapesten hangzott el a Szemere Bertalan Magyar Rendvédelem-történeti Tudományos Társaság által szervezett rendvédelem-történeti tudományos konferencia-sorzatnak. „A Napóleoni közbiztonsági örtestület útja Párizstól — Itálián és Ausztrián keresztül - Budapestig." címü VIII. konferenciáján. A publikált tanulmány az előadás javított, bővített és átdolgozott változata.

KIsS Gábor: Csendőrök az emigrációban. Rendvédelem-történeti Füzetek (Acta Historiae Praesidii Ordinis), VII.évf. (1997) 8.sz. 60-61.p. HU-ISSN 1216-6774. A tanulmány korábbi változata 1996. október 29-én, Budapesten hangzott el a Szemere Bertalan Magyar Rendvédelem-történeti Tudományos Társaság által szervezett rendvédelem-történeti tudományos konferencia-sorzatnak. „A Napóleoni közbiztonsági örtestület útja Párizstól - Itálián és Ausztrián keresztül - Budapestig." címü VIII. konferenciáján. A publikált tanulmány az előadás javított, bővített és átdolgozott változata.

Kiss István Géza: A Magyar Királyi csendőrség hagyományai, muzeális emlékanyagainak örzési helyei hazánkban és külföldön. Rendvédelem-történeti Füzetek (Acta Historiae Praesidii Ordinis), VII.évf. (1997) 8.sz. 6267.p. HU-ISSN 1216-6774. A tanulmány korábbi változata 1996. október 29-én, Budapesten hangzott el a Szemere Bertalan Magyar Rendvédelemtörténeti Tudományos Társaság által szervezett rendvédelem-történeti tudományos konferencia-sorzatnak. „A Napóleoni közbiztonsági örtestület útja Párizstól - Itálián és Ausztrián keresztül - Budapestig. ” című VIII. konferenciáján. A publikált tanulmány az előadás javított, bővített és átdolgozott változata.

KoMÁROMI Gábor: A Magyar Királyi Csendőrség szervezeti változásai 1919-1925 között. Rendvédelem-történeti Füzetek (Acta Historiae Praesidii Ordinis), IV.évf. (1994) 5.sz. 90-91.p. HU-ISSN 1216-6774. A tanulmány korábbi változata 1993. szeptember 21-én, Budapesten hangzott el a Szemere Bertalan Magyar Rendvédelem-történeti Tudományos Társaság által 
MARKÓ

(10.;)

OLASZ

(10;)

ÖRY

$(4 . ; 10 ;)$ szervezett rendvédelem-történeti tudományos konferencia-sorzatnak. „Háború, forradalom, trianon. ” című V. konferenciáján. A publikált tanulmány az előadás javított, bővített és átdolgozott változata.

MARKÓ György: Csendőrtisztek a Magyar Királyi Honvéd Vezérkar fönökének bírósága elött. Rendvédelem-történeti Füzetek (Acta Historiae Praesidii Ordinis), XXI.évf. (2011) 24.sz. 73-79.p. HU-ISSN 1216-6774. A tanulmány korábbi változata 2009. december 3-án, Budapesten hangzott el a Szemere Bertalan Magyar Rendvédelem-történeti Tudományos Társaság által szervezett rendvédelem-történeti tudományos konferencia-sorzatnak. „Csendörség Ausztria-Magyarországon, illetve Ausztriában és Magyarországon 1849-2005. ” címủ XXVI. konferenciáján. A publikált tanulmány az előadás javított, bővített és átdolgozott változata.

OLASZ Lajos: A légi csendőrség Magyarországon. Rendvédelem-történeti Füzetek (Acta Historiae Praesidii Ordinis), XXIII.évf. (2013) 31-32-3334.sz. 105-120.p. A tanulmány korábbi változata 2013. október 4-én, Budapesten hangzott el a Szemere Bertalan Magyar Rendvédelem-történeti Tudományos Társaság által szervezett rendvédelem-történeti tudományos konferencia-sorzatnak. „A magyar rendvédelem, légiközlekedés, felderités a XIX-XX. században.” címü XXVIII. konferenciáján. A publikált tanulmány az előadás javított, bővített és átdolgozott változata.

ŐRY Károly: A Maréchaussée-tól a Gendarmerie Nationale-ig. A francia csendőrség történelmi előzményei. Rendvédelem-történeti Füzetek (Acta Historiae Praesidii Ordinis), VII.évf. (1997) 8.sz. 75-77.p. HU-ISSN 1216-6774. A tanulmány korábbi változata 1996. október 29-én, Budapesten hangzott el a Szemere Bertalan Magyar Rendvédelem-történeti Tudományos Társaság által szervezett rendvédelem-történeti tudományos konferencia-sorzatnak. „A napóleoni közibztonsági örtestület útja Párizstól — Itálián és Ausztrián keresztül - Budapestig" című VIII. konferenciáján. A publikált tanulmány az előadás javított, bővített és átdolgozott változata.

PARÁDI Ákos: Ludovikai indítvány a magyar csendőrség létrehozására. Rendvédelem-történeti Füzetek (Acta Historiae Praesidii Ordinis), XXIV.évf. (2014) 39-40-41-42.sz. 51-54.p. HU-ISSN 1216-6774.

PARÁDI Ákos: Hivatástörténet-gondozás a Magyar Királyi Csendőrségnél. Rendvédelem-történeti Füzetek (Acta Historiae Praesidii Ordinis), XXIV.évf. (2014) 39-40-41-42.sz. 55-60.p. HU-ISSN 1216-6774.

PARÁDI József: A dualista Magyarország belügyi szervei. Belügyi Szemle, XXXIV.évf. (1986) 4.sz. 45-50.p. HU-ISSN 0133-6738.

szág belügyi szervei.

(5.;)

PARÁDI József: A polgári magyar állam első központosított közbiztonsági szervezete a Magyar Királyi Csendőrség.

(3.,)

PARÁDI József: A dualizmus közrendvédelmi szerveinek jellemzői és tevékenységük tapasztalatai.

PARÁDI József: A Magyar Királyi Csendőrség megalakulása és müködése 18811918.

(10.;35.;)

PARÁDI József: A határszéli csendőrség állambiztonsági feladatai.

(10.;)
PARÁDI József: A polgári magyar állam első központosított közbiztonsági szervezete a Magyar Királyi Csendőrség. Belügyi Szemle, XXXVII.évf. (1989) 2.sz. 35-40.p. HU-ISSN 0133-6738.

PARÁDI József: A dualizmus közrendvédelmi szerveinek jellemzői és tevékenységük tapasztalatai. Rendvédelem-történeti Füzetek (Acta Historiae Praesidii Ordinis), II.évf. (1992) 3.sz. 21-28.p. HU-ISSN 1216-6774. A tanulmány korábbi változata 1991. november 19-én, Budapesten hangzott el a Szemere Bertalan Magyar Rendvédelem-történeti Tudományos Társaság által szervezett rendvédelem-történeti tudományos konferencia-sorzatnak. ,,Traelőadás javított, bővített és átdolgozott változata.

PARÁDI József: A Magyar Királyi Csendőrség megalakulása és működése 1881-1918. Rendvédelem-történeti Füzetek (Acta Historiae Praesidii Ordinis), VII. évf. (1997) 8.sz. 78-83.p. HU-ISSN 1216-6774. A tanulmány korábbi változata 1996. október 29-én Budapesten hangzott el a Szemere Bertalan Magyar Rendvédelem-történeti Tudományos Társaság által szervezett rendvédelem-történeti tudományos konferenciasorozatnak. „A napóleoni közbiztonsági örtestület útja Párizstól - Itálián és Ausztrián keresztül - Budapestig" címü VIII. konferenciáján. A publikált tanulmány az előadás javított, bővített és átdolgozott változata.

PARÁDI József: A határszéli csendőrség állambiztonsági feladatai. Rendvédelem-történeti Füzetek (Acta Historiae Praesidii Ordinis), XI.évf. (2005) 14.sz. 91-94.p. HU-ISSN 1216-6774. A tanulmány korábbi változata 2000, november 8-án, Budapesten hangzott el a Szemere Bertalan Magyar Rendvédelem-történeti Tudományos Társaság által szervezett rendvédelem-történeti tudományos konferenciasorozatnak. „Az ezeréves magyar rendvédelem” címü XIV. konferenciáján. A publikált tanulmány az előadás javított, bővített és átdolgozott változata. díció és korszerüség” című III. konferenciáján. A publikált tanulmány az 
PARÁDI József: A csendőr tisztképzés és a fizetési osztályba sorolt állami alkalmazottak szakvizsga rendszere. (10.;)

PARÁDI József: A magyar rendvédelem személyi állományának humán viszonyai 1867-1945.

(7.;)

PARÁDI József: A csendőrség magyaror- szági története.

(10.;)

PARÁDI József: Tények és érzelmek egy hajdani magyar rendvédelmi testület története kapcsán.

(10.;)

PARÁDI József: A Magyar Királyi Csendőrség határőrizeti szolgálata.

(10.;)

PARÁDI József: A polgári magyar állam rendvédelmi testületeinek humán viszonyai 1867-1945.

(7.;)

PARÁdI József: A Magyar Királyi Csen- - dörség szervezete.

(10.;17.;21.;)

PARÁDI József: A Magyar Királyi Csendőrség szolgálati tevékenységei.

(8.,10;)
PARÁDI József: A csendőr tisztképzés és a fizetési osztályba sorolt állami alkalmazottak szakvizsga rendszere. Rendvédelem-történeti Füzetek (Acta Historiae Praesidii Ordinis), XIII.évf. (2007) 16.sz. 100-104.p. HU-ISSN 12166774. A tanulmány korábbi változata 2002. november 12-én, Budapesten hangzott el a Szemere Bertalan Magyar Rendvédelem-történeti Tudományos Társaság által szervezett rendvédelem-történeti tudományos konferencia-sorozatnak. „A rendvédelmi szakképzés története” címü XIV. konferenciáján. A publikált tanulmány az előadás javított, bővített és átdolgozott változata.

PARÁDI József: A magyar rendvédelem személyi állományának humán viszonyai 1867-1945. Rendvédelem-történeti Füzetek (Acta Historiae Praesidii Ordinis), XIV.évf. (2008) 17.sz. 57-87.p. HU-ISSN 1216-6774. A tanulmány korábbi változata 2003. november 11-én, Budapesten hangzott el a Szemere Bertalan Magyar Rendvédelem-történeti Tudományos Társaság által szervezett rendvédelem-történeti tudományos konferencia-sorozatnak. „A rendvédelem humán viszonyai" című XVII. konferenciáján. A publikált tanulmány az elöadás javított, bővített és átdolgozott változata.

PARÁDI József: A csendőrség magyarországi története. Rendvédelemtörténeti Füzetek (Acta Historiae Praesidii Ordinis), XVI.évf. (2009) 19.sz. 64-88.p. HU-ISSN 1216-6774. A tanulmány korábbi változata 2005. október 6-án, Budapesten hangzott el a Szemere Bertalan Magyar Rendvédelem-történeti Tudományos Társaság által szervezett rendvédelem-történeti tudományos konferencia-sorozatnak. „Másfél évtized nemzeti rendvédelem-történetünk kutatásának szolgálatában” címü XIX. konferenciáján. A publikált tanulmány az előadás javított, bővített és átdolgozott változata.

PARÁDI József: Tények és érzelmek egy hajdani magyar rendvédelmi testület története kapcsán. Rendvédelem-történeti Füzetek (Acta Historiae Praesidii Ordinis), XVII.évf. (2009) 20.sz. 93-99.p. HU-ISSN 1216-6774. A tanulmány korábbi változata 2006. szeptember 29-én, Budapesten hangzott el a Szemere Bertalan Magyar Rendvédelem-történeti Tudományos Társaság által szervezett rendvédelem-történeti tudományos konferencia-sorozatnak. „A XIX-XX. századi magyar forradalmak hatása a nemzeti rendvédelmi rendszerünkre" címü XX. konferenciáján. A publikált tanulmány az előadás javított, bővített és átdolgozott változata.

PARÁDI József: A Magyar Királyi Csendőrség határőrizeti szolgálata. Rendvédelem-történeti Füzetek (Acta Historiae Praesidii Ordinis), XIX.évf. (2010) 22.sz. 77-91.p. HU-ISSN 1216-6774. A tanulmány korábbi változata 2008. október 10-én, Budapesten hangzott el a Szemere Bertalan Magyar Rendvédelem-történeti Tudományos Társaság által szervezett rendvédelem-történeti tudományos konferencia-sorozatnak. „Másfél évszázad rendszerváltozásainak hatásai nemzeti rendvédelmünkre" címü XXII. Konferenciáján. A publikált tanulmány az előadás javított, bővített és átdolgozott változata.

PARÁDI József: A polgári magyar állam rendvédelmi testületeinek humán viszonyai 1867-1945. Rendvédelem-történeti Füzetek (Acta Historiae Praesidii Ordinis), XIX.évf. (2010) 22.sz. 92-114.p. HU-ISSN 1216-6774. A tanulmány korábbi változata 2008. október 10-én, Budapesten hangzott el a Szemere Bertalan Magyar Rendvédelem-történeti Tudományos Társaság által szervezett rendvédelem-történeti tudományos konferencia-sorozatnak. „Másfél évszázad rendszerváltozásainak hatásai nemzeti rendvédelmünkre” címü XXII. konferenciáján. A publikált tanulmány az előadás javított, bővített és átdolgozott változata.

PARÁDI József: A Magyar Királyi Csendőrség szervezete. Rendvédelemtörténeti Füzetek (Acta Historiae Praesidii Ordinis), XXI.évf. (2011) 24.sz. 80-90.p. HU-ISSN 1216-6774. A tanulmány korábbi változata 2009. december 3-án, Budapesten hangzott el a Szemere Bertalan Magyar Rendvédelem-történeti Tudományos Társaság által szervezett rendvédelem-történeti tudományos konferencia-sorozatnak. „Csendörség Ausztria-Magyarországon, illetve Ausztriában és Magyarországon 1849-2005." című XXIV. konferenciáján. A publikált tanulmány az előadás javított, bővített és átdolgozott változata.

PARÁDI József: A Magyar Királyi Csendőrség szolgálati tevékenységei. Rendvédelem-történeti Füzetek (Acta Historiae Praesidii Ordinis), XXI.évf. (2011) 24.sz. 91-99.p. HU-ISSN 1216-6774. A tanulmány korábbi változata 2009. december 3-án hangzott el a Szemere Bertalan Magyar Rendvédelemtörténeti Tudományos Társaság által szervezett magyar rendvédelem-történeti tudományos konferencia-sorozatnak a „Csendőrség Ausztria-Magyarországon, 
PARÁDI József: A csendőrség teendői az Osztrák-Magyar Monarchia Magyar Királysága külső határainak örzésében. $(10 . ;)$

PARÁDI József: A XIX-XX. századi magyar rendszerváltozások és a csendőrség. (10.;)

PARÁDI József: Az Osztrák-Magyar Monarchia Magyar Királyságának határszéli csendörsége.

(10.;)

PARÁDI József: Az egységes állami fizetési rendszer és a szakterületi rendfokozati rendszerek a polgári magyar állam rendvédelmében.

(7.;)

PARÁDI József: A Császári Királyi Csendőrség Magyarországon.

(10.;)

PERJÉSI

(10.;)

RAVASZ

(10.;)

SALLAI: A határszéli csendőrség fegyverhasználata.

(10.;)

SALLAI: Francia, osztrák, magyar csendörség fegyverhasználata a XIX. században.

(10.;) illetve Ausztriában és Magyarországon 1849-2005. " című XXIV. konferenciáján. A publikált tanulmány az előadás javított, bővített és átdolgozott változata.

PARÁDI József: A csendőrség teendői az Osztrák-Magyar Monarchia Magyar Királysága külső határainak őrzésében. Rendvédelem-történeti Füzetek (Acta Historiae Praesidii Ordinis), XXI.évf. (2011) 24.sz. 100-118.p. HU-ISSN 1216-6774. A tanulmány korábbi változata 2009. december 3-án hangzott el a Szemere Bertalan Magyar Rendvédelem-történeti Tudományos Társaság által szervezett magyar rendvédelem-történeti tudományos konferencia-sorozatnak a „Csendörség Ausztria-Magyarországon, illetve Ausztriában és Magyar-országon 1849-2005” címủ XXIV. konferenciáján. A publikált tanulmány az előadás javított, bővített és átdolgozott változata.

PARÁDI József: A XIX-XX. századi magyar rendszerváltozások és a csendörség. Rendvédelem-történeti Füzetek (Acta Historiae Praesidii Ordinis), XXII.évf. (2012) 25.sz. 102-110.p. HU-ISSN 1216-6774. A tanulmány korábbi változata 2010. december 6-án hangzott el a Szemere Bertalan Magyar Rendvédelem-történeti Tudományos Társaság által szervezett magyar rendvédelemtörténeti tudományos konferencia-sorozatnak a „, A közbiztonság közös Kárpátmedence-i örökségünk” című XXV. konferenciáján. A publikált tanulmány az előadás javított, bővített és átdolgozott változata.

PARÁDI József: Az Osztrák-Magyar Monarchia Magyar Királyságának határszéli csendörsége. Rendvédelem-történeti Füzetek (Acta Historiae Praesidii Ordinis), XXII.évf. (2012) 26.sz. 81-104.p. HU-ISSN 1216-6774.

PARÁDI József: Az egységes állami fizetési rendszer és a szakterületi rendfokozati rendszerek a polgári magyar állam rendvédelmében. Rendvédelem-történeti Füzetek (Acta Historiae Praesidii Ordinis), XXII.évf. (2012) 26.sz. 105-119.p. HU-ISSN 1216-6774. A tanulmány korábbi változata 2011. november 11-én hangzott Budapesten el a Szemere Bertalan Magyar Rendvédelem-történeti Tudományos Társaság által szervezett magyar rendvédelem-történeti tudományos konferencia-sorozatnak a „Militarizmus és demilitarizmus a XIX-XX. századi magyar állam rendvédelmében” címü XXVI. konferenciáján. A publikált tanulmány az előadás javított, bővített és átdolgozott változata.

PARÁDI József: A Császári Királyi Csendörség Magyarországon. Rendvédelem-történeti Füzetek (Acta Historiae Praesidii Ordinis), XXIV.évf. (2014) 39-40-41-42.sz. 61-70.p. HU-ISSN 1216-6774.

PERJÉSI György ifj. : A Magyar Királyi Csendőrség létszámalakulása 1938 1945. Rendvédelem-történeti Füzetek (Acta Historiae Praesidii Ordinis), XIII. évf. (2007) 16.sz. 105-106.p. HU-ISSN 1216-6774. A tanulmány korábbi változata 2002. november 12-én hangzott el Budapesten a Szemere Bertalan Magyar Rendvédelem-történeti Tudományos Társaság által szervezett magyar rendvédelem-történeti tudományos konferencia-sorozatnak a „A rendvédelmi szakképzés története" című XVI. konferenciáján. A publikált tanulmány az előadás javított, bővített és átdolgozott változata.

RAVASz István: Csendőrpuccs, vagy zászlószentelés? A budapesti deportálások leállítása. Rendvédelem-történeti Füzetek (Acta Historiae Praesidii Ordinis), VII.évf. (1997) 8.sz. 84-87.p. HU-ISSN 1216-6774. A tanulmány korábbi változata 1996. október 29-én hangzott el, Budapesten a Szemere Bertalan Magyar Rendvédelem-történeti Tudományos Társaság által szervezett magyar rendvédelem-történeti tudományos konferencia-sorozatnak a „A napóleoni közbiztonsági örtestület útja Párizstól — Itálián és Ausztrián keresztül — Budapestig." címü VIII. konferenciáján. A publikált tanulmány az előadás javított, bővített és átdolgozott változata.

SALlAi János: A határszéli csendőrség fegyverhasználata. Rendvédelemtörténeti Füzetek (Acta Historiae Praesidii Ordinis), VII. évf. (1997) 8.sz. 8890.p. HU-ISSN 1216-6774. A tanulmány korábbi változata 1996. október 29én hangzott el, Budapesten a Szemere Bertalan Magyar Rendvédelem-történeti Tudományos Társaság által szervezett magyar rendvédelem-történeti tudományos konferencia-sorozatnak a „A napóleoni közbiztonsági örtestület útja Párizstól — Itálián és Ausztrián keresztül - Budapestig." című VIII. konferenciáján. A publikált tanulmány az előadás javított, bővített és átdolgozott változata.

SALLAI János: Francia, osztrák, magyar csendőrség fegyverhasználata a XIX. században. Rendvédelem-történeti Füzetek (Acta Historiae Praesidii Ordinis), IX.évf. (1999.) 10.sz. 154-159.p. HU-ISSN 1216-6774. A tanulmány korábbi változata 1998 szeptember 22-én hangzott el, Budapesten a Szemere Bertalan 
SÁGVÁRI

(10.;)

SimON: A Magyar Királyi Csendőrség szolgálati teendői a vagyonbiztonság ellen irányuló büncselekmények megelőzésében és felderítésében.

(10.;)

SimON: Egy kiérdemelt emlékbélyeg és egy nem érdemelt megbélyegzés története.

SuBA: A Magyar Királyi Csendőrség szerepe az északi demarkációs vonalon 1919-1923.

(10.;)

SuBA: Határcsendőr zászlóaljak 1919 1921. Áttérés a katonai határőrizetre. (10.;)

SubA: A Magyar Királyi Csendőrség létszámának tervezett felemelése 1918-ban. (10.;)

SuBA: 1918 forró nyara és a Magyar Királyi Csendörség.

(10.;)

SuBA: A Magyar Királyi Csendőrség és a vasútbiztonság 1917-1918.
Magyar Rendvédelem-történeti Tudományos Társaság által szervezett magyar rendvédelem-történeti tudományos konferencia-sorozatnak a „, A nyugati rendvédelem hatása a XIX-XX. századi magyar rendvédelemre." címü X. konferenciáján. A publikált tanulmány az elöadás javított, bővített és átdolgozott változata.

SÁGVÁRI György: Csendőr és rendőr egyenruhák a dualizmus kori Magyarországon. Rendvédelem-történeti Füzetek (Acta Historiae Praesidii Ordinis), III.évf. (1993) 4.sz. 161-169.p. HU-ISSN 1216-6774. A tanulmány korábbi változata 1992. szeptember 29-én hangzott el, Budapesten a Szemere Bertalan Magyar Rendvédelem-történeti Tudományos Társaság által szervezett magyar rendvédelem-történeti tudományos konferencia-sorozatnak a „A dualista Magyarország rendvédelme.” címü IV. konferenciáján. A publikált tanulmány az előadás javított, bővített és átdolgozott változata.

SIMON Ferenc: A Magyar Királyi Csendőrség szolgálati teendői a vagyonbiztonság ellen irányuló büncselekmények megelőzésében és felderítésében. Rendvédelem-történeti Füzetek (Acta Historiae Praesidii Ordinis), VIII.évf. (1998) 9.sz. 45-48.p. HU-ISSN 1216-6774. A tanulmány korábbi változata 1997. szeptember 22-én hangzott el, Budapesten a Szemere Bertalan Magyar Rendvédelem-történeti Tudományos Társaság által szervezett magyar rendvédelem-történeti tudományos konferencia-sorozatnak a „, Gazdasági rendvédelmünk a XIX-XX. században. ” címü IX. konferenciáján. A publikált tanulmány az előadás javított, bővített és átdolgozott változata.

SiMON Ferenc Egy kiérdemelt emlékbélyeg és egy nem érdemelt megbélyegzés története. Rendvédelem-történeti Füzetek (Acta Historiae Praesidii Ordinis), IX.évf. (1999) 10.sz. 160-163.p. HU-ISSN 1216-6774. A tanulmány korábbi változata 1998. szeptember 22-én hangzott el, Budapesten a Szemere Bertalan Magyar Rendvédelem-történeti Tudományos Társaság által szervezett magyar rendvédelem-történeti tudományos konferencia-sorozatnak a „A nyugati rendvédelem hatása a XIX-XX. századi magyar rendvédelemre." címü X. konferenciáján. A publikált tanulmány az előadás javított, bővített és átdolgozott változata.

SuBA János: A Magyar Királyi Csendőrség szerepe az északi demarkációs vonalon 1919-1923. Rendvédelem-történeti Füzetek (Acta Historiae Praesidii Ordinis), VII.évf. (1997) 8.sz. 91-94.p. HU-ISSN 1216-6774. A tanulmány korábbi változata 1996. október 29-én hangzott el, Budapesten a Szemere Bertalan Magyar Rendvédelem-történeti Tudományos Társaság által szervezett magyar rendvédelem-történeti tudományos konferencia-sorozatnak a „, A napóleoni közbiztonsági örtestület útja Párizstól - Itálián és Ausztrián keresztül — Budapestig” című VIII. konferenciáján. A publikált tanulmány az előadás javított, bővített és átdolgozott változata.

SuBA János: Határcsendőr zászlóaljak 1919-1921. Áttérés a katonai határőrizetre. Rendvédelem-történeti Füzetek (Acta Historiae Praesidii Ordinis), XII.évf. (2007) 15.sz. 182-191.p. HU-ISSN 1216-6774. A tanulmány korábbi változata 2001. november 6-án hangzott el, Budapesten a Szemere Bertalan Magyar Rendvédelem-történeti Tudományos Társaság által szervezett magyar rendvédelem-történeti tudományos konferencia-sorozatnak a „Az európai és a magyar rendvédelem a XIX-XX. században" címü XV. konferenciáján. A publikált tanulmány az előadás javított, bővített és átdolgozott változata.

SuBA János: A Magyar Királyi Csendőrség létszámának tervezett felemelése 1918-ban. Rendvédelem-történeti Füzetek (Acta Historiae Praesidii Ordinis), XIII. évf. (2007) 16.sz. 113-120.p. HU-ISSN 1216-6774. A tanulmány korábbi változata 2002. november 12-én hangzott el, Budapesten a Szemere Bertalan Magyar Rendvédelem-történeti Tudományos Társaság által szervezett magyar rendvédelem-történeti tudományos konferencia-sorozatnak a „A rendvédelmi szakképzés története” címü XVI. konferenciáján. A publikált tanulmány az előadás javított, bővített és átdolgozott változata.

SuBA János: 1918 forró nyara és a Magyar Királyi Csendőrség. Rendvédelem-történeti Füzetek (Acta Historiae Praesidii Ordinis), XXI.évf. (2011) 24.sz. 119-125.p. HU-ISSN 1216-6774. A tanulmány korábbi változata 2009. december 3-án hangzott el, Budapesten a Szemere Bertalan Magyar Rendvédelem-történeti Tudományos Társaság által szervezett magyar rendvédelemtörténeti tudományos konferencia-sorozatnak a „Csendörség Ausztria-Magyarországon, illetve Ausztriában és Magyarországon 1849-2005” címü XXIV. konferenciáján. A publikált tanulmány az előadás javított, bővített és átdolgozott változata.

SuBA János: A Magyar Királyi Csendőrség és a vasútbiztonság 1917-1918. Rendvédelem-történeti Füzetek (Acta Historiae Praesidii Ordinis), XXI.évf. (2011) 
SuBA: A császári csendőrség tiszti kara $1849-1868$

SuBA: A Magyar Királyi Csendőrség és a terület-visszacsatolások.

(10.;)

SZAKÁLY: Néhány gondolat a volt Ma- _ gyar Királyi Csendőrségröl.

(10.;)

SZAKÁLY: A két világháború közötti rendvédelmi szervek tevékenységének néhány jellemzője.

(10.;)

SZAKÁLY: A Magyar Királyi Csendőrség az első központosított magyar közbiztonsági őrtestület.

(10.;)

SZAKÁLY: Az Osztrák-Magyar Monarchia hadseregének tábori csendőrsége (Rövid áttekintés).

(10.;)

SZAKÁLY: A Magyar Királyi Csendőrség 1919-1941.

(10.;)

SZAKÁLY: Akik a Magyar Királyi Csendörséget — 1938 és 1945 között — vezették.

(10.;) 24.sz. 126-135.p. HU-ISSN 1216-6774. A tanulmány korábbi változata 2009. december 3-án hangzott el, Budapesten a Szemere Bertalan Magyar Rendvédelemtörténeti Tudományos Társaság által szervezett magyar rendvédelem-történeti tudományos konferencia-sorozatnak a ,,Csendörség Ausztria-Magyarországon, illetve Ausztriában és Magyarországon 1849-2005” címü XXIV. konferenciáján. A publikált tanulmány az előadás javított, bővített és átdolgozott változata.

SuBA János: A császári csendőrség tiszti kara 1849-1868. Rendvédelem-történeti Füzetek (Acta Historiae Praesidii Ordinis), XXII.évf. (2012) 25.sz. 116128.p. HU-ISSN 1216-6774. A tanulmány korábbi változata 2010. december 6án hangzott el, Budapesten a Szemere Bertalan Magyar Rendvédelem-történeti Tudományos Társaság által szervezett magyar rendvédelem-történeti tudományos konferencia-sorozatnak „A közbiztonság közös Kárpát-medence-i örökségünk” címü XXV. konferenciáján. A publikált tanulmány az előadás javított, bövített és átdolgozott változata.

SuBA János: A Magyar Királyi Csendőrség és a terület-visszacsatolások. Rendvédelem-történeti Füzetek (Acta Historiae Praesidii Ordinis), XXIV.évf. (2014) 39-40-41-42.sz. 119-130.p. HU-ISSN 1216-6774.

SzAKÁLY Sándor: Néhány gondolat a volt Magyar Királyi Csendőrségröl. Rendvédelem-történeti Füzetek (Acta Historiae Praesidii Ordinis), I.évf. (1991) 1.sz. 38-44.p. HU-ISSN 1216-6774. A tanulmány korábbi változata 1990. április 24-én hangzott el, Budapesten a Szemere Bertalan Magyar Rendvédelem-történeti Tudományos Társaság által szervezett magyar rendvédelemtörténeti tudományos konferencia-sorozatnak , A magyar rendvédelmi testületek és az önkormányzati szervezetek kapcsolata 1848-1945" címü I. konferenciáján. A publikált tanulmány az előadás javított, bővített és átdolgozott változata.

SZAKÁLY Sándor: A két világháború közötti rendvédelmi szervek tevékenységének néhány jellemzője. Rendvédelem-történeti Füzetek (Acta Historiae Praesidii Ordinis), II.évf. (1992) 3.sz. 29-34.p. HU-ISSN 1216-6774. A tanulmány korábbi változata 1991. november 19-én hangzott el, Budapesten a Szemere Bertalan Magyar Rendvédelem-történeti Tudományos Társaság által szervezett magyar rendvédelem-történeti tudományos konferencia-sorozatnak „Tradició és korszerüség” címü III. konferenciáján. A publikált tanulmány az előadás javított, bővített és átdolgozott változata.

SZAKÁLY Sándor: A Magyar Királyi Csendőrség az első központosított magyar közbiztonsági örtestület. Rendvédelem-történeti Füzetek (Acta Historiae Praesidii Ordinis), III.évf. (1993) 4.sz. 51-58.p. HU-ISSN 1216-6774. A tanulmány korábbi változata 1992. szeptember 29-én hangzott el, Budapesten a Szemere Bertalan Magyar Rendvédelem-történeti Tudományos Társaság által szervezett magyar rendvédelem-történeti tudományos konferencia-sorozatnak „A dualista Magyarország rendvédelme” címü IV. konferenciáján. A publikált tanulmány az előadás javított, bővített és átdolgozott változata.

SzAKÁLY Sándor: Az Osztrák-Magyar Monarchia hadseregének tábori csendőrsége (Rövid áttekintés). Rendvédelem-történeti Füzetek (Acta Historiae Praesidii Ordinis), IV.évf. (1994) 5.sz. 55-58.p. HU-ISSN 1216-6774. A tanulmány korábbi változata 1993. szeptember 21-én hangzott el, Budapesten a Szemere Bertalan Magyar Rendvédelem-történeti Tudományos Társaság által szervezett magyar rendvédelem-történeti tudományos konferencia-sorozatnak „Háború, forradalom, trianon" című V. konferenciáján. A publikált tanulmány az előadás javított, bővített és átdolgozott változata.

SzAKÁLy Sándor: A Magyar Királyi Csendőrség 1919-1941. Rendvédelemtörténeti Füzetek (Acta Historiae Praesidii Ordinis), V.évf. (1995) 6.sz. 122129.p. HU-ISSN 1216-6774. A tanulmány korábbi változata 1994 októberében, hangzott el, Budapesten a Szemere Bertalan Magyar Rendvédelem-történeti Tudományos Társaság által szervezett magyar rendvédelem-történeti tudományos konferencia-sorozatnak „A két világháború közötti Magyar Királyság rendvédelme" címủ VI. konferenciáján. A publikált tanulmány az előadás javított, bővített és átdolgozott változata.

SzAKÁLY Sándor: Akik a Magyar Királyi Csendőrséget - 1938 és 1945 között - vezették. Rendvédelem-történeti Füzetek (Acta Historiae Praesidii Ordinis), XXI.évf. (2011) 24.sz. 136-153.p. HU-ISSN 1216-6774. A tanulmány korábbi változata 2009. december 3-án, hangzott el, Budapesten a Szemere Bertalan Magyar Rendvédelem-történeti Tudományos Társaság által szervezett magyar rendvédelem-történeti tudományos konferencia-sorozatnak „Csendörség Ausztria-Magyarországon, illetve Ausztriában és Magyarországon 18492005” címü XXIV. konferenciáján. A publikált tanulmány az előadás javított, bővített és átdolgozott változata. 
SZELEI

$(10 . ;)$

SzÜCS

(10.;)

TAMÁSKA

(10.;)

VARRÓ: Rádió közvetítés az ungvári csendőr iskolából. „Székely fiúkból nevelik a magyar csendöröket" közvetítés az ungvári csendőr iskolából.

(10.;)

VARRÓ: Hatvan éves a Magyar Királyi _ Csendörség.

(10.;)

Vedó: A Magyar Királyi Csendőrség karhatalmi tevékenységének szabályozása a dualizmus idején.

(10.;)

VEDÓ: Rádió a Magyar Királyi Csendőrség szolgálatában.

(10.;)

Vedó: A Magyar Királyi Csendőrség karhatalmi fellépésének gyakorlata. (10.;)

VEDÓ: A haderő karhatalmi tevékenysé- ge 1867-1918.

(10.;)

VEDÓ: A Francia Nemzeti Csendőrség a két világháború között.

(10.;)
SzELEI József: Katonából csendőr, csendőrből járörvezető. Rendvédelemtörténeti Füzetek (Acta Historiae Praesidii Ordinis), VII.évf. (1997) 8.sz. 103104.p. HU-ISSN 1216-6774. A tanulmány korábbi változata 1996. október 29én, hangzott el, Budapesten a Szemere Bertalan Magyar Rendvédelem-történeti Tudományos Társaság által szervezett magyar rendvédelem-történeti tudományos konferencia-sorozatnak „A napóleoni közbiztonsági örtestület útja Párizstól — Itálián és Ausztrián keresztül - Budapestig." címü VIII. konferenciáján. A publikált tanulmány az előadás javított, bővített és átdolgozott változata.

SzÜCs János: A francia csendőrség helye, feladatai napjainkban Rendvédelem-történeti Füzetek (Acta Historiae Praesidii Ordinis), . IX.évf. (1999) 10.sz. 189-191.p. HU-ISSN 1216-6774. A tanulmány korábbi változata 1998. szeptember 22-én, hangzott el, Budapesten a Szemere Bertalan Magyar Rendvédelem-történeti Tudományos Társaság által szervezett magyar rendvédelemtörténeti tudományos konferencia-sorozatnak ,, A nyugati rendvédelem hatása a XIX-XX. századi magyar rendvédelemre.” címü X. konferenciáján. A publikált tanulmány az előadás javított, bővített és átdolgozott változata.

TAMÁSKA Endre: Egy csendör őrs országos tekintélye. Rendvédelemtörténeti Füzetek (Acta Historiae Praesidii Ordinis), IX.évf. (1999) 10.sz. 1218.p. HU-ISSN 1216-6774. A tanulmány korábbi változata 1998. szeptember 22-én, hangzott el, Budapesten a Szemere Bertalan Magyar Rendvédelemtörténeti Tudományos Társaság által szervezett magyar rendvédelem-történeti tudományos konferencia-sorozatnak , A nyugati rendvédelem hatása a XIX-XX. századi magyar rendvédelemre.” címü X. konferenciáján. A publikált tanulmány az előadás javított, bővített és átdolgozott változata.

VARRÓ István Tamás: Rádió közvetítés az ungvári csendőr iskolából. „Székely fiúkból nevelik a magyar csendőröket” közvetítés az ungvári csendőr iskolából. Rendvédelem-történeti Füzetek (Acta Historiae Praesidii Ordinis), XII.évf. (2007) 15.sz. 212-219.p. HU-ISSN 1216-6774. A tanulmány korábbi változata 2001. november 6-án, hangzott el, Budapesten a Szemere Bertalan Magyar Rendvédelem-történeti Tudományos Társaság által szervezett magyar rendvédelem-történeti tudományos konferencia-sorozatnak ,Az európai és a magyar rendvédelem a XIX-XX. században" címü XV. konferenciáján. A publikált tanulmány az előadás javított, bővített és átdolgozott változata.

VARRÓ István Tamás: Hatvan éves a Magyar Királyi Csendőrség. Rendvédelem-történeti Füzetek (Acta Historiae Praesidii Ordinis), XIII.évf. (2007) 16.sz. 140-146.p. HU-ISSN 1216-6774. A tanulmány korábbi változata 2002. november 12-én, hangzott el, Budapesten a Szemere Bertalan Magyar Rendvédelem-történeti Tudományos Társaság által szervezett magyar rendvédelemtörténeti tudományos konferencia-sorozatnak ,A rendvédelmi szakképzés története” című XVI. konferenciáján. A publikált tanulmány az előadás javított, bövített és átdolgozott változata.

VEDÓ Attila: A Magyar Királyi Csendőrség karhatalmi tevékenységének szabályozása a dualizmus idején. Rendvédelem-történeti Füzetek (Acta Historiae Praesidii Ordinis), XXIII.évf. (2013) 31-32-33-34.sz. 170-184.p. HUISSN 1216-6774.

VEDÓ Attila: Rádió a Magyar Királyi Csendőrség szolgálatában. Rendvédelem-történeti Füzetek (Acta Historiae Praesidii Ordinis), XXIV.évf. (2014) 3940-41-42.sz. 131-142.p. HU-ISSN 1216-6774.

VEDÓ Attila: A Magyar Királyi Csendőrség karhatalmi fellépésének gyakorlata. Rendvédelem-történeti Füzetek (Acta Historiae Praesidii Ordinis), XXIV.évf. (2014) 39-40-41-42.sz. 143-154.p. HU-ISSN 1216-6774.

VEDÓ Attila: A haderő karhatalmi tevékenysége 1867-1918. Rendvédelemtörténeti Füzetek (Acta Historiae Praesidii Ordinis), XXIV.évf. (2014) 39-4041-42.sz. 155-165.p. A tanulmány korábbi változata 2014. X. 17-én, hangzott el, Budapesten a Szemere Bertalan Magyar Rendvédelem-történeti Tudományos Társaság által szervezett magyar rendvédelem-történeti tudományos konferencia-sorozatnak „A magyar rendvédelem a kivételes hatalom idöszakában” címü XXX. konferenciáján. A publikált tanulmány az előadás javított, bővített és átdolgozott változata.

VEDÓ Attila: A Francia Nemzeti Csendőrség a két világháború között. Rendvédelem-történeti Füzetek (Acta Historiae Praesidii Ordinis), XXIII.évf. (2013) 31-32-33-34.sz. 185-196.p. A tanulmány korábbi változata 2013. II. 15én, hangzott el, Budapesten a Szemere Bertalan Magyar Rendvédelem-történeti Tudományos Társaság Csendőrség-történeti Szakosztálya és az ELTE-ÁJK Magyar Állam- és Jogtörténeti Tanszék által szervezett magyar rendvédelemtörténeti tudományos szimpozion sorozatnak , $A$ XIX-XX. századi európai és 
ZACHAR: Fejezetek az osztrák csendőrség történetéből 1849-1918. $(10 . ; 14 . ;)$

ZACHAR: A HABSBURG-hatalom és a magyar rendvédelem.

$(15 . ;)$

ZEIDLER

$(10 . ;)$

ZÉTÉNYI Zsolt: A Magyar Királyi Csendörség és a csendőrök jogállása 1945-ben és azután. (Egy elfelejtett szervezet és jelmondat: „Híven, becsülettel, vitézül!”) (10.;)

\section{CIKKEK}

ANIK

(33.;)

ВЕÖTHY

(25.;)

SOLTÉSZ

(29.;)

S. százados: Az éjjeli portyázás.

\section{SZABÁLYZATOK}

Kimutatás a szolgálati könyvekröl, szabályokról és utasitásokról a Magyar Királyi Honvédség, a népfölkelés és a csendörség számára.

(13.;)

Laktanya-szabályok a Magyar Királyi Csendörség számára.

(37.;)

SZUT-1881

(13.;26.;)

SZUT-1887

(13.;27.;)

SZUT-1896

(13.;) magyarországi csendőrségek” címü XIII. szimpozionján. A publikált tanulmány az előadás javított, bővített és átdolgozott változata.

ZACHAR József: Fejezetek az osztrák csendőrség történetéből 1849-1918. Rendvédelem-történeti Füzetek (Acta Historiae Praesidii Ordinis VII.évf. (1997) 8.sz. 105-109.p. HU-ISSN 1216-6774. A tanulmány korábbi változata 1996. október 29-én, hangzott el, Budapesten a Szemere Bertalan Magyar Rendvédelem-történeti Tudományos Társaság által szervezett magyar rendvédelem-történeti tudományos konferencia-sorozatnak „A napóleoni közbiztonsági örtestület útja Párizstól — Itálián és Ausztrián keresztül - Budapestig”" címü VIII. konferenciáján. A publikált tanulmány az előadás javított, bővített és átdolgozott változata.

ZACHAR József: A HABSBURG-hatalom és a magyar rendvédelem. Rendvédelem-történeti Füzetek (Acta Historiae Praesidii Ordinis), IX.évf. (2005) 14.sz. 146-149.p. HU-ISSN 1216-6774. A tanulmány korábbi változata 2000. november 8-án, hangzott el, Budapesten a Szemere Bertalan Magyar Rendvédelem-történeti Tudományos Társaság által szervezett magyar rendvédelem-történeti tudományos konferencia-sorozatnak „Az ezeréves magyar rendvédelem” című XIV. konferenciáján. A publikált tanulmány az előadás javított, bővített és átdolgozott változata.

ZEIDLER Sándor: A Magyar Királyi Csendőrség rendfokozati rendszere és jelvényei. Rendvédelem-történeti Füzetek (Acta Historiae Praesidii Ordinis VII.évf. (1997) 8.sz. 110-112.p. HU-ISSN 1216-6774. A tanulmány korábbi változata 1996. október 29-én, hangzott el, Budapesten a Szemere Bertalan Magyar Rendvédelem-történeti Tudományos Társaság által szervezett magyar rendvé-delem-történeti tudományos konferencia-sorozatnak „A napóleoni közbizton-sági örtestület útja Párizstól — Itálián és Ausztrián keresztül — Budapestig” címü VIII. konferenciáján. A publikált tanulmány az elöadás javított, bővített és átdolgozott változata.

ZÉTÉNYI Zsolt: A Magyar Királyi Csendőrség és a csendőrök jogállása 1945ben és azután. (Egy elfelejtett szervezet és jelmondat: „Híven, becsülettel, vitézül!") Rendvédelem-történeti Füzetek (Acta Historiae Praesidii Ordinis XXI.évf. (2011) 24.sz. 154-165.p. HU-ISSN 1216-6774. A tanulmány korábbi változata 2009. december 3-án, hangzott el, Budapesten a Szemere Bertalan Magyar Rendvédelem-történeti Tudományos Társaság által szervezett magyar rendvédelem-történeti tudományos konferencia-sorozatnak „A csendörség Ausztria-Magyarországon, illetve Ausztriában és Magyarországon 18492005. ” címủ XXIV. konferenciáján. A publikált tanulmány az előadás javított, bővített és átdolgozott változata.

ANIK János: A megelőző szolgálat és a nyomozás, Csendörségi Lapok, II.évf (1908) 14.sz. 157-159.p.

BЕÖтну Kálmán: A világjáró csendőr. Csendőrségi Lapok, XVIII.évf. (1928) 28.sz. 765-768.p.

SoLTÉsz Imre: A járőrtalálkozásokról, Csendőrségi Lapok, II.évf. (1908) 51.sz. 601-604.p.

S. százados: Az éjjeli portyázás, Csendőrségi Lapok, VIII.évf. (1914) 9.sz. 97-99.p.

Kimutatás a szolgálati könyvekröl, szabályokról és utasitásokról a Magyar Királyi Honvédség, a népfölkelés és a csendörség számára. Budapest, 1898, Pallas. 19 p.

Laktanya-szabályok a Magyar Királyi Csendörség számára. Budapest, 1889, Pesti Könyvnyomda. 43 p.

Utasitás a Magyar Királyi Csendôrség számára. Budapest, 1881, Pesti Könyvnyomda. $191 \mathrm{p}$.

Szervezeti és szolgálati utasitás a Magyar Királyi Csendőrség számára. Budapest, 1887, Központi Községi Nyomda. (A II. és III. kiadás 1888 és 1889, melyeket — a második fejezet tekintetében — 1900-ban módosítottak.)

Általános szolgálati határozványok a Magyar Királyi Csendörség számára. Budapest 1896, Pesti Könyvnyomda. 275 p. 
SZUT-1903

(13.;)

SZUT-1912

(13.;)

SZUT-1927

(13.;)

SZUT-1941

(13.;)

Útmutató a csendör járörök részére. $(13 . ; 40 . ;)$

JOGSZABÁLYMAGYARÁZATOK NÉMETHY

(23.;)

\section{JOGSZABÁLYOK}

$1881 /$ II.tc.

(16.;)

1881/III.tc.

(16.;)

$1882 /$ X.tc.

(22.;)
Utasitások a Magyar Királyi Csendörség számára. Budapest, 1903, s.n. 78 p.

Utasitások a Magyar Királyi Csendőrség számára. Budapest, 1912, Várnay és fia „Municipia” Kiadó hivatal. 360 p.

- Szervezeti és szolgálati utasitás a Magyar Királyi Csendörség számára. Budapest, 1927, Pallas. 387 p.

- Szervezeti és szolgálati utasitás a Magyar Királyi Csendörség számára. Budapest, 1941, Stádium Sajtóvállalat. 411 p.

Útmutató a csendőr járörök részére. Máramarossziget, 1908, Kaufman Ábra-hám és társai. $57 \mathrm{p}$.

NÉMETHY Ferenc: A Magyar Királyi Csendörség szervezete, szolgálata és viszonya közigazgatási hatóságokhoz. A Magyar Királyi Csendörség hatásköre, jogai szolgálati teendői és eljárása. I. köt. 72 p. A Magyar Királyi Csendörség viszonya közigazgatási hatóságokhoz. II. köt. (II. és III. rész) 162 p. Budapest, 1900, Országos Központi Községi Nyomda Rt. /Közigazgatási Könyvtár/

— 1881/II.tc. a csendőrség legénységi állományának a kiegészítéséről.

— 1881/III.tc. a közbiztonsági szolgálat szervezéséről.

1882/X.tc. a Magyar Királyi Csendőrség által, a törvényhatósági joggal felruházott városok kül- és belterületein való teljesitendőkről. 